\title{
32. BENTHIC FORAMINIFERAL CARBON ISOTOPIC RECORDS AND THE DEVELOPMENT OF ABYSSAL CIRCULATION IN THE EASTERN NORTH ATLANTIC ${ }^{1}$
}

\author{
Kenneth G. Miller and Richard G. Fairbanks, Lamont-Doherty Geological Observatory of Columbia University \\ and \\ Ellen Thomas, Scripps Institution of Oceanography ${ }^{2}$
}

\begin{abstract}
The North Atlantic at present is ventilated by overflow of the Denmark Strait, Iceland-Faeroe Ridge, Faeroe Bank Channel, and Wyville-Thompson Ridge. The evolution of Cenozoic abyssal circulation of this region was related to tectonic opening and subsidence of these sills. We used $\delta^{13} \mathrm{C}$ records of the benthic foraminifer Cibicidoides to decipher the timing of tectonically controlled changes in bottom-water circulation in the eastern basins (Biscay and Iberian) of the northern North Atlantic. Records from Site 608 (Kings Trough, northeastern North Atlantic) show that from about 24 to $15 \mathrm{Ma}$ (early to early middle Miocene), $\delta^{13} \mathrm{C}$ values in the Kings Trough area were depleted relative to western North Atlantic values and were more similar to Pacific $\delta^{13} \mathrm{C}$ values. This reflects less ventilation of the Kings Trough region as compared to the well-oxygenated western North Atlantic. Comparison of Oligocene $\delta^{13} \mathrm{C}$ records from Site 119 (Bay of Biscay) with western North Atlantic records suggests that the eastern basin was also relatively isolated prior to $24 \mathrm{Ma}$. At about $15 \mathrm{Ma}, \delta^{13} \mathrm{C}$ values at Site 608 attained values similar to the western North Atlantic, indicating increased eastern basin ventilation in the middle Miocene. This increased advection into the eastern basin predated a major $\delta^{18} \mathrm{O}$ increase which occurred at about 14.6 Ma. Subsidence estimates of the Greenland-Scotland Ridge indicate that the deepening of the Iceland-Faeroe Ridge was coincident with the marked change in eastern basin deep-water ventilation.
\end{abstract}

\section{INTRODUCTION AND PREVIOUS WORK}

In the Quaternary, high-frequency $\left(10^{4}-10^{5}\right.$ yr.) abyssal circulation changes were climatically controlled (e.g., Curry and Lohmann, 1983, 1985). Cenozoic abyssal circulation changes on the $10^{6}$ - to $10^{7}$-yr. scale, however, may be related either to long-term climatic or to tectonically controlled changes (e.g., Miller and Tucholke, 1983). Reconstructions of tectonic passageways allow evaluation of the causes of abyssal circulation changes. The history of basin development in the Cenozoic North Atlantic is a history of progressive tectonic enlargement and opening of passages that apparently resulted in increased bottom-water circulation (Berggren and Hollister, 1972; Miller and Tucholke, 1983). These tectonic changes had a profound effect upon global abyssal circulation and ocean chemistry, including loci of deposition of organic carbon, silica, and carbonate (Berger, 1970).

The history of Cenozoic bottom-water formation in the North Atlantic and its marginal seas has been controversial (cf., Schnitker, 1979, 1980a, b, with Miller and Tucholke, 1983). Today, North Atlantic Deep Water (NADW) is formed by a mixture of Norwegian-Greenland Sea Overflow Water, Labrador Sea Water, and entrained North Atlantic Water (Worthington, 1976; Broecker and Peng, 1983). Based upon evidence of changes in composition of benthic foraminiferal faunas in the eastern North Atlantic, Schnitker (1979) suggested that the first analogue of NADW formed in the middle Mio-

\footnotetext{
${ }^{1}$ Ruddiman, W. F., Kidd, R. B., Thomas, E., et al., Init. Repts. DSDP, 94: Washington (U.S. Govt. Printing Office).

2 Addresses: (Miller and Fairbanks) Lamont-Doherty Geological Observatory of Columbia University, Palisades, NY 10964; (Thomas, present address) Lamont-Doherty Geological Observatory of Columbia University, Palisades, NY 10964.
}

cene, subsequent to the subsidence of the Iceland-Faeroe Ridge. Miller and Tucholke (1983) presented seismic stratigraphic evidence from the eastern and western North Atlantic, which suggested that an analogue to NADW first formed near the end of the Eocene, and this has been substantiated for the western North Atlantic by carbon isotopic studies (Miller and Fairbanks, 1983, 1985). They suggested that Oligocene-Miocene bottom waters formed in the Arctic/Norwegian-Greenland Sea and flowed over sills in the proto-Denmark Straits and Faeroe Bank Channel, although they acknowledged that the Labrador Sea and northern North Atlantic were also possible sources (Figs. 1, 2) (Miller and Tucholke, 1983). We used carbon isotopes to evaluate possible sources of bottom-water supply to the eastern basins of the northern North Atlantic, and specifically to evaluate whether the deep eastern basins were isolated from the western basins.

Carbon isotopic comparisons provide strong evidence for the nature and timing of changes in North Atlantic bottom waters. Although changes in lithology and benthic foraminiferal fauna provide supportive evidence for abyssal circulation changes, they are rarely diagnostic by themselves. Benthic foraminiferal $\delta^{13} \mathrm{C}$ analyses have proven to be useful in reconstructing the history of Quaternary abyssal circulation changes (Curry and Lohmann, 1982, 1983, 1985; Boyle and Keigwin, 1982; Shackleton et al., 1983; Mix and Fairbanks, in press; Fairbanks and Mix, in press). Curry and Lohmann (1985) demonstrated that the deep eastern equatorial Atlantic basin was isolated from the western Atlantic during Pleistocene ice ages, but was well mixed during interglacial periods. We have previously applied such tactics to Quaternary $\delta^{13} \mathrm{C}$ records to decipher $10^{6}$ - to $10^{7}-$ yr. abyssal circulation changes for the western North Atlantic during the Oli- 


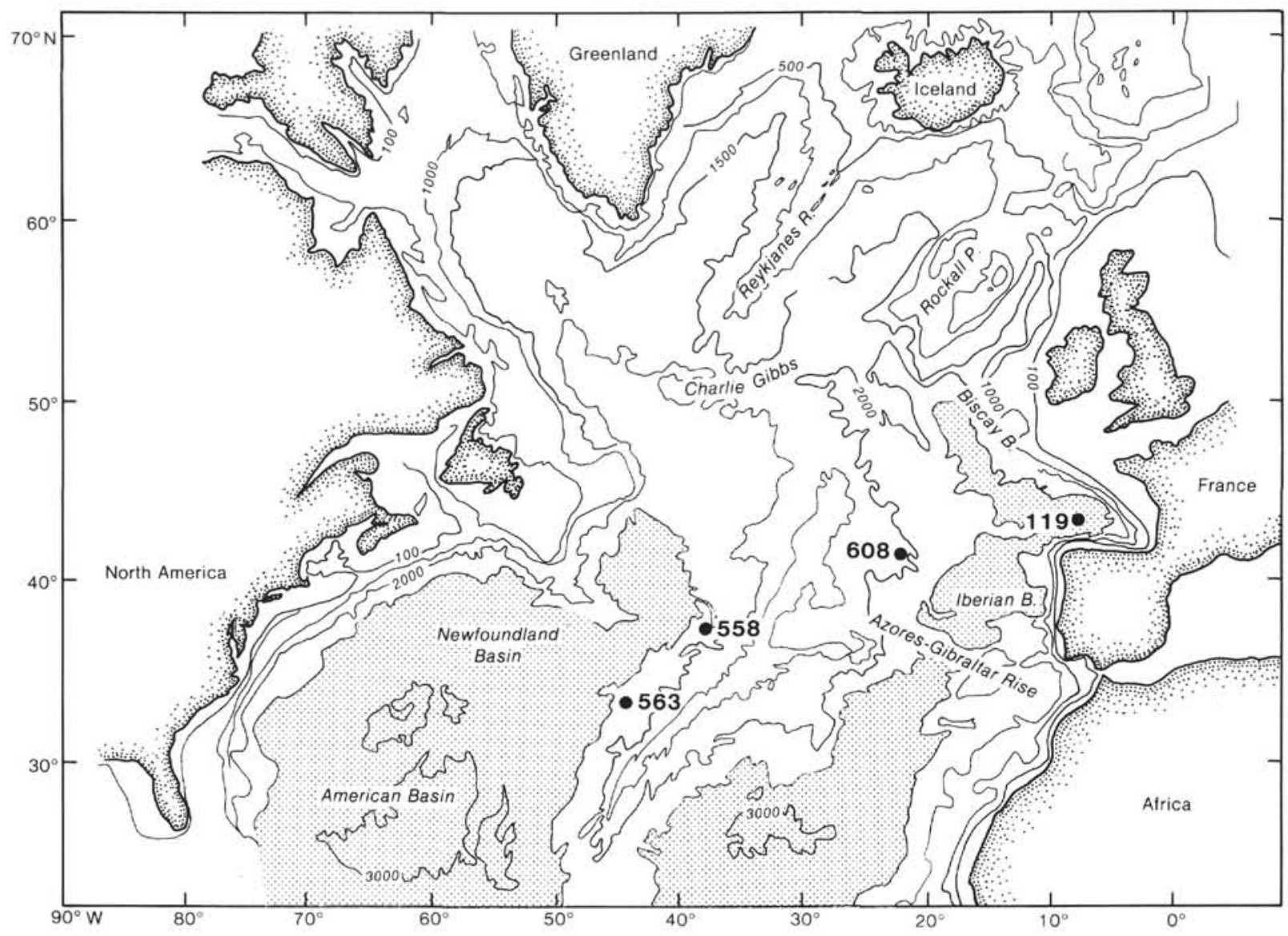

Figure 1. Bathymetric location map of the northern North Atlantic in fathoms. Modern basins deeper than 2500 fm are stippled; 1500 fm contour (heavy line) included to outline northern basins (after U.S. Naval Oceanographic Office, 1964).

gocene-Miocene (Miller and Fairbanks, 1983, 1985; Miller and Thomas, 1985).

Various investigators have delineated aperiodic Oligocene-Miocene global cycles in $\delta^{13} \mathrm{C}$ of benthic and planktonic foraminifers, with peak values at ca. $36,25,16$, and $9 \mathrm{Ma}$ (Miller and Fairbanks, 1983, 1985; Shackleton et al., 1984; Miller and Thomas, 1985; Woodruff and Savin, 1985; Vincent and Berger, 1985; Vincent et al., 1985). These global Cenozoic cycles were related to changes in the input or output ratio of organic carbon to carbonate carbon (Miller and Fairbanks, 1985).

Differences between the global isotopic signal and regional signals provide evidence of regional abyssal circulation changes (Curry and Lohmann, 1982; Shackleton et al., 1983; Mix and Fairbanks, in press; Fairbanks and Mix, in press). Because Pacific deep waters compose the bulk of the oceanic reservoir (Baumgartner and Reichel, 1975), Pacific deep-water $\delta^{13} \mathrm{C}$ records can be used to approximate the global $\delta^{13} \mathrm{C}$ signal. Synoptic time series offsets between Atlantic $\delta^{13} \mathrm{C}$ records and Pacific records can be compared with the modern ocean offsets: present-day Atlantic bottom waters are higher in $\delta^{13} \mathrm{C}$ than those of the Pacific, reflecting production of nutrient-depleted and ${ }^{13} \mathrm{C}$-enriched NADW (Kroopnick et al., 1972; Kroopnick, 1974, 1980, 1985). A similar carbon isotopic difference was noted to exist between the western North Atlantic (American-Newfoundland ba- sins) and the Pacific in the early Oligocene and Miocene, suggesting the supply of "young," nutrient-depleted and ${ }^{13} \mathrm{C}$-enriched bottom water in a mode similar to that of today (Miller and Fairbanks, 1983, 1985; Miller and Thomas, 1985).

We attempted to isolate Miocene abyssal circulation changes by making interbasinal (eastern North Atlantic versus Pacific and versus western North Atlantic) comparisons of $\delta^{13} \mathrm{C}$ records (Table 1). Our comparisons suggest that the eastern (Biscay-Iberian) and western (American-Newfoundland) basins of the northern North Atlantic had different circulation histories until the middle Miocene, but that bottom-water changes have been similar in these basins since about $15 \mathrm{Ma}$.

\section{METHODS}

All isotopic data considered here were performed on mixed species of the benthic foraminiferal taxon Cibicidoides (Table 2). This taxon secretes calcite tests that are offset from $\delta^{18} \mathrm{O}$ equilibrium by $0.65 \%$ and that reflect the distribution of $\delta^{13} \mathrm{C}$ of $\Sigma \mathrm{CO}_{2}$ in the modern ocean (Shackleton and Opdyke, 1973; Duplessy et al., 1980; Woodruff et al., 1980; Belanger et al., 1981; Graham et al., 1981). Sample preparation and isotopic procedures are given by Miller and Thomas (1985). Ages are reported using the Berggren et al. (in press a, b) time scale by interpolating between magnetostratigraphic (Site 608: Clement and Robinson, this volume; Site 563: Miller, Aubry, et al., 1985) and biostratigraphic (Sites 77, 119, 289, and 563) datum levels (Table 3; Figs. 4-6).

Our sampling interval at Site 608 averages 0.4 m.y. We believe that our record resolves changes on the million-year scale fairly well. For 
A
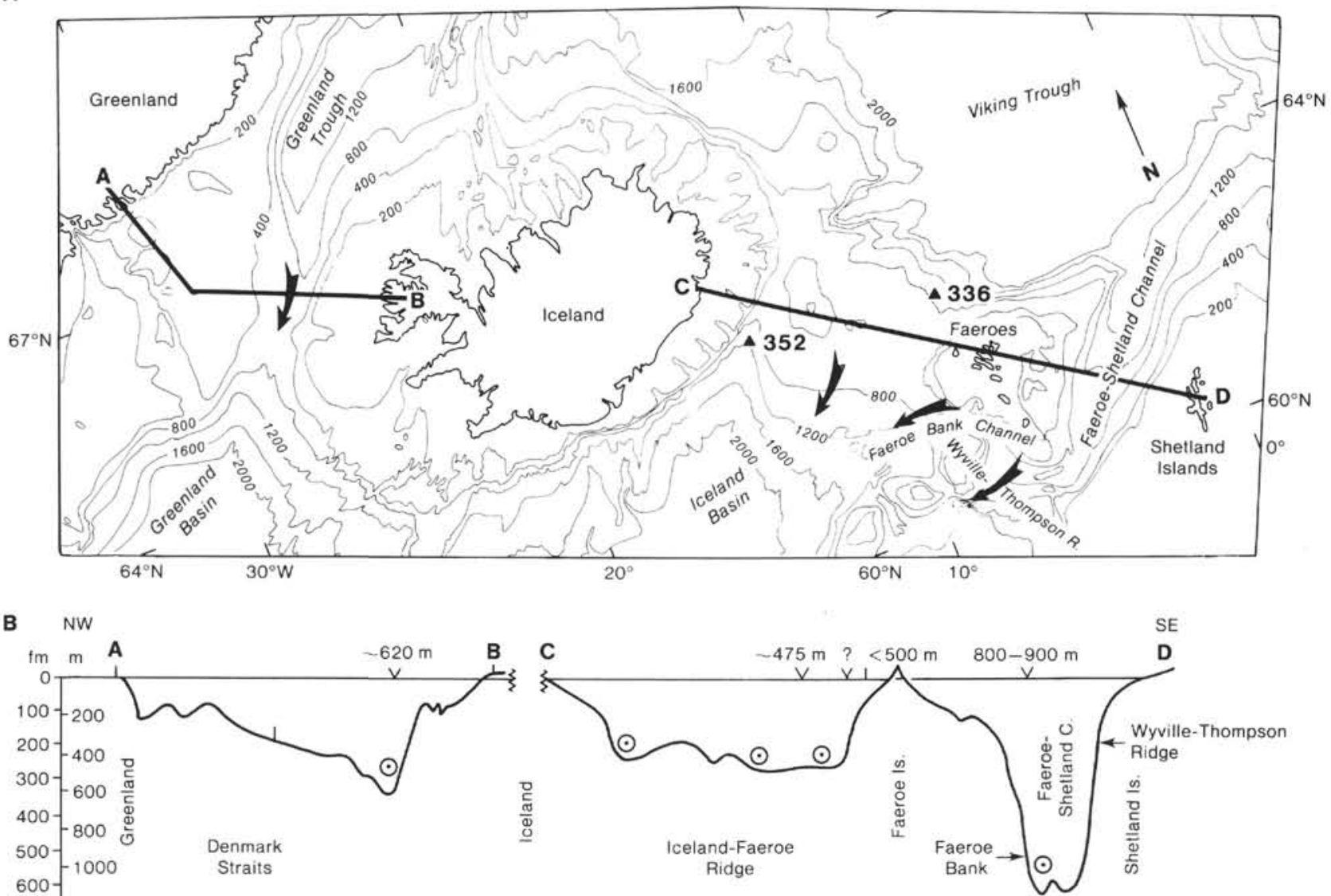

$800-1400 \quad 500$ VE $-500.1 \quad \mathrm{~km}=$ sill depth

Figure 2. A. Bathymetry of the Greenland-Scotland Ridge, in meters. Arrows indicate modern overflow routes (after Miller and Tucholke, 1983). B. Bathymetric cross section of the Greenland-Scotland Ridge (located in Fig. 2A) showing maximum sill depths (after Miller and Tucholke, 1983). Section does not cross sill depths of Faeroe Bank Channel and Wyville-Thompson Ridge, which are indicated with arrows. (See text and Figure 7 for explanation of lines A-B and C-D.)

Table 1. Oxygen and carbon isotopic records.

\begin{tabular}{|c|c|c|c|c|}
\hline $\begin{array}{l}\text { DSDP } \\
\text { site }\end{array}$ & Location & $\begin{array}{l}\text { Present } \\
\text { water depth } \\
\text { (m) }\end{array}$ & Age & Reference \\
\hline 608 & $\begin{array}{l}\text { Kings Trough, eastern North Atlantic } \\
\left(42^{\circ} 50.21^{\prime} \mathrm{N}, 23^{\circ} 05.25^{\prime} \mathrm{W}\right)\end{array}$ & 3526 & Miocene & This chapter \\
\hline 77 & $\begin{array}{l}\text { Eastern Equatorial Pacific } \\
\left(00^{\circ} 28.90^{\prime} \mathrm{N}, 133^{\circ} 13.70^{\prime} \mathrm{W}\right)\end{array}$ & 4291 & Miocene & Savin et al., 1981 \\
\hline 289 & $\begin{array}{l}\text { Western Equatorial Pacific } \\
\left(00^{\circ} 29.29^{\prime} \mathrm{S}, 15^{\circ} 30.69^{\prime} \mathrm{E}\right)\end{array}$ & 2206 & Miocene & Savin et al., 1981 \\
\hline 119 & $\begin{array}{l}\text { Bay of Biscay }\left(45^{\circ} 01.90^{\prime} \mathrm{N},\right. \\
\left.07^{\circ} 58.49^{\prime} \mathrm{W}\right)\end{array}$ & 4447 & Oligocene & $\begin{array}{l}\text { Miller and Curry, } \\
1982\end{array}$ \\
\hline 563 & $\begin{array}{l}\text { Western North Atlantic }\left(33^{\circ} 38.53^{\prime} \mathrm{N} \text {, }\right. \\
\left.43^{\circ} 46.04^{\prime} \mathrm{W}\right)\end{array}$ & 3793 & Miocene-Oligocene & $\begin{array}{l}\text { Miller and Fairbanks, } \\
1985\end{array}$ \\
\hline
\end{tabular}

example, the $\delta^{13} \mathrm{C}$ record at Site 608 adequately represents the global carbon isotopic record noted at more closely sampled Sites 77,289 , and 563 (Figs. 4, 5).

Diagenesis may alter the isotopic record, especially at deeply buried (greater than 400-m) sites (Miller and Curry, 1982; Killingley, 1983). We argue that the Miocene of Site 608 (Fig. 3) is substantially unaltered. Oxygen isotopic values at Site $608 \mathrm{mimic}$ the patterns found at Site 563 (Fig. 5), even in the finer-scaled variations noted between 25 and $15 \mathrm{Ma}$ (Fig. 5). This similarity occurs between sections with substantially different burial depths $(240-300 \mathrm{~m}$ sub-bottom at Site 563 versus $300-400 \mathrm{~m}$ at Site 608), and argues against extensive diagenetic recrys- tallization of the calcite tests. In addition, samples from Miocene sections with burial depths of less than $100 \mathrm{~m}$ to greater than $600 \mathrm{~m}$ (including those from Site 608) show no decrease in $\delta^{18} \mathrm{O}$ values with burial depth as postulated by Killingley (1983), suggesting that the sections described here are not substantially altered.

\section{HYDROGRAPHIC AND BATHYMETRIC SETTING}

The modern bottom-water temperature and salinity characteristics at Sites 608 and 563 fall within the defini- 
Table 2. Oxygen and carbon isotopic values for mixed species of Cibicidoides, Hole 608 (reported to PDB standard).

\begin{tabular}{|c|c|c|c|c|}
\hline $\begin{array}{c}\text { Sample } \\
\text { (core-section, } \\
\text { interval in } \mathrm{cm} \text { ) }\end{array}$ & $\begin{array}{l}\text { Sub-bottom } \\
\text { depth } \\
\text { (m) }\end{array}$ & $\begin{array}{l}\mathrm{Age}^{\mathrm{a}} \\
(\mathrm{Ma})\end{array}$ & $\delta^{18} \mathrm{O}$ & $\delta^{13} \mathrm{C}$ \\
\hline $17, \mathrm{CC}$ & 156.40 & 6.0 & 2.29 & 1.07 \\
\hline $18, \mathrm{CC}$ & 164.80 & 6.5 & 2.01 & 1.09 \\
\hline $21, \mathrm{CC}$ & 192.45 & 8.0 & 2.01 & 1.09 \\
\hline $22-2,86-92$ & 197.26 & 8.3 & 2.00 & 1.25 \\
\hline $22, \mathrm{CC}$ & 202.90 & 8.7 & 1.87 & 0.87 \\
\hline $23-3,88-93$ & 208.38 & 9.0 & 2.02 & 0.77 \\
\hline $23, \mathrm{CC}$ & 214.10 & 9.2 & 1.72 & 0.94 \\
\hline $24-3,74-79$ & 217.84 & 9.3 & 1.25 & 0.94 \\
\hline $24, \mathrm{CC}$ & 223.55 & 9.5 & 1.61 & 1.08 \\
\hline $25, \mathrm{CC}$ & 233.30 & 9.9 & 1.71 & 0.75 \\
\hline $26-3,73-78$ & 237.03 & 10.0 & 1.83 & 0.90 \\
\hline $26, \mathrm{CC}$ & 241.23 & 10.2 & 1.85 & 1.20 \\
\hline $27-3,47-52$ & 246.37 & 10.4 & 1.69 & 0.79 \\
\hline $27-6,47-53$ & 250.87 & 10.6 & 1.57 & 1.11 \\
\hline $28, \mathrm{CC}$ & 261.20 & 11.3 & 1.92 & 1.05 \\
\hline $29, \mathrm{CC}$ & 271.00 & 11.9 & 1.87 & 1.16 \\
\hline $30-3,15-20$ & 274.85 & 12.2 & 1.14 & 0.86 \\
\hline $31-1,85-90$ & 282.15 & 12.7 & 1.69 & 0.91 \\
\hline $32-3,38-40$ & 294.30 & 13.5 & 1.40 & 1.26 \\
\hline $32-5,80-85$ & 297.70 & 13.7 & 1.54 & 1.60 \\
\hline $33-1,25-27$ & 300.75 & 13.9 & 1.08 & 1.57 \\
\hline $33-1,52-56$ & 301.00 & 13.9 & 1.31 & 1.70 \\
\hline $34-1,62-63$ & 310.72 & 14.6 & 0.81 & 1.28 \\
\hline $34-3,28-30$ & 313.38 & 14.7 & 0.82 & 1.07 \\
\hline $34-4,90-92$ & 315.50 & 14.9 & 0.95 & 1.22 \\
\hline $35-3,90-92$ & 323.60 & 15.5 & 0.97 & 1.51 \\
\hline $36-3,38-40$ & 332.68 & 16.4 & 0.97 & 1.30 \\
\hline $36-5,38-40$ & 335.68 & 16.7 & 0.57 & 0.92 \\
\hline $38-6,38-40$ & 356.38 & 18.8 & 1.00 & 0.68 \\
\hline $39-3,38-40$ & 361.48 & 19.3 & 0.76 & 0.60 \\
\hline $40-2,85-90$ & 370.05 & 20.0 & 1.00 & 0.24 \\
\hline $40, \mathrm{CC}$ & 376.01 & 20.5 & 1.20 & 0.67 \\
\hline $41-4,107-112$ & 382.87 & 21.0 & 1.08 & 0.54 \\
\hline $41-6,86-91$ & 385.66 & 21.2 & 0.95 & 0.28 \\
\hline $42-3,100-105$ & 390.90 & 21.6 & 0.97 & 0.67 \\
\hline $42-5,86-91$ & 393.76 & 21.8 & 1.03 & 0.59 \\
\hline $43-3,110-115$ & 400.06 & 22.3 & 0.77 & 0.81 \\
\hline $43-5,10-15$ & 402.60 & 22.5 & 0.70 & 1.06 \\
\hline $44-2,10-15$ & 407.70 & 22.9 & 0.98 & 1.75 \\
\hline $44-4,38-40$ & 410.98 & 23.2 & 0.98 & 1.20 \\
\hline $45-3,38-40$ & 419.08 & 23.8 & 0.94 & 1.06 \\
\hline $45-4,38-40$ & 420.58 & 23.9 & 0.94 & 0.71 \\
\hline $45-5,38-40$ & 422.08 & 24.0 & 1.21 & 0.55 \\
\hline $46-3,24-26$ & 428.54 & 24.5 & 1.14 & 0.61 \\
\hline
\end{tabular}

a Ages computed using age model 1, Table 3A.

Table 3A. Site 608 age model 1.

\begin{tabular}{lcr}
\hline \multicolumn{1}{c}{ Criterion } & $\begin{array}{c}\text { Sub-bottom } \\
\text { depth } \\
(\mathrm{m})\end{array}$ & $\begin{array}{r}\text { Age } \\
\text { (Ma) }\end{array}$ \\
\hline Gauss/Gilbert boundary & 109.31 & 3.40 \\
Chron 10/C5 boundary & 206.99 & 8.92 \\
base Chron C5n & 248.00 & 10.42 \\
base Chron C5Bn & 321.60 & 15.27 \\
top Chron 6C & 361.60 & 19.35 \\
base Chron C6Cn & 424.44 & 24.20 \\
Chron C8/C9 & 448.00 & 28.15 \\
\hline
\end{tabular}

Note: Table 3A-G age model parameters were obtained by linear interpolation. Table $3 \mathrm{~A}$ was used to construct Figures 4 and $5 \mathrm{~A}$, and employs magnetostratigraphy of Clement and Robinson (this volume) and Figure 3 by parsimoniously selecting prominent, unambiguous chron boundaries (Fig. 3). Interpretations of base Chron $\mathrm{C} 6 \mathrm{Cn}$ differ from Clement and Robinson (this volume); see Figure 3.
Table 3B. Site 608 age model 2.

\begin{tabular}{lcc}
\hline \multicolumn{1}{c}{ Criterion } & $\begin{array}{c}\text { Sub-bottom } \\
\text { depth } \\
(\mathrm{m})\end{array}$ & $\begin{array}{c}\text { Age } \\
(\mathrm{Ma})\end{array}$ \\
\hline Gauss/Gilbert & 3.4 & 109.31 \\
Chron 6/7 & 6.7 & 170.09 \\
Chron 9/10 & 8.5 & 199.66 \\
Chron 10/C5 & 8.92 & 206.99 \\
Chron C5/C5A & 11.55 & 263.00 \\
Chron C5A/C5AA & 13.20 & 297.97 \\
Chron C5AD/C5B & 14.87 & 316.99 \\
Chron C5B/C5C & 16.22 & 332.09 \\
Chron C5C/C5D & 17.57 & 344.37 \\
Chron C5D/C5E & 18.56 & 353.26 \\
Chron C5E/C6 & 19.35 & 361.61 \\
Chron C6/C6A & 20.88 & 388.73 \\
Chron C6A/C6AA & 21.90 & 391.57 \\
Chron C6AA/C6B & 22.60 & 407.85 \\
Chron C6B/C6C & 23.30 & 424.44 \\
\hline
\end{tabular}

Note: This table used to construct Figure SB, and employs magnetostratigraphy of Clement and Robinson (this volume) by interpolating between most chron boundaries.

Table 3C. Site 563 age model 1.

\begin{tabular}{lcc}
\hline \multicolumn{1}{c}{ Criterion } & $\begin{array}{c}\text { Sub-bottom } \\
\text { depth } \\
(\mathrm{m})\end{array}$ & $\begin{array}{c}\text { Age } \\
(\mathrm{Ma})\end{array}$ \\
\hline Base Chron C4An & 159.5 & 8.2 \\
Base Chron C5n & 188.0 & 10.4 \\
Top Chron C5An & 204.5 & 11.9 \\
Base Chron C5Bn & 242.5 & 15.3 \\
Top Chron C5Cn & 251.0 & 16.2 \\
Top Chron C5Dn & 260.0 & 17.6 \\
Base Chron C5dN & 267.0 & 18.1 \\
& Unconformity 270.5 & From 18.4 to 19.4 \\
Base Chron C6n & 277.5 & 20.5 \\
Top Chron C6c & 296.5 & 23.27 \\
Top Chron C8 & 315.5 & 26.86 \\
Base Chron C8n & 323.5 & 27.74 \\
Top Chron C12 & 337.0 & 32.46 \\
Base C12n & 339.2 & 32.90 \\
Earliest Chron C12 & 360.1 & 35.28 \\
\hline
\end{tabular}

Note: Used to construct Figure 5A; magnetostratigraphy after Miller, Aubry, et al. (1985).

tion of NADW (Worthington, 1976). Site 608 lies near Discovery Stations 3891 and 3889 (potential temperatures $2.69^{\circ} \mathrm{C}$ and $2.75^{\circ} \mathrm{C}$, salinities $34.931 \% 0$ and $34.945 \%$, respectively), and Site 563 lies near Discovery Station $3628\left(2.37^{\circ} \mathrm{C}, 34.905 \% 0\right)$ (Fuglister, 1960).

Bottom waters in the eastern basins north of the Azores-Gibraltar Rise (Fig. 1) today reflect several sources. Iceland-Faeroe Ridge, Faeroe Bank Channel, and Wyville-Thompson Ridge overflow waters (Fig. 2) are major constituents of NADW in the eastern basins, termed Northeast Atlantic Deep Water (NEADW) (Lee and Ellett, 1965). The eastern basins, however, export most of the overflow waters to the western basins through the Charlie Gibbs Fracture Zone, and the overflows apparently do not directly contribute to the ventilation of the Iberian or Biscay basins below the $2.4^{\circ} \mathrm{C}$ potential temperature surface (Fig. 1) (Broecker et al., 1985). At present, the major source of ventilation for the deep basins (temperatures below $2.4^{\circ} \mathrm{C}$; below about $3250 \mathrm{~m}$ ) is advection from the south (Broecker and Peng, 1983; Broeck- 
Table 3G. Site 119 age model.

Table 3D. Site 563 age model 2 .

\begin{tabular}{cc}
\hline $\begin{array}{c}\text { Sub-bottom } \\
\text { depth } \\
(\mathrm{m})\end{array}$ & $\begin{array}{c}\text { Age } \\
\text { (Ma) }\end{array}$ \\
\hline 157.69 & 8.15 \\
189.90 & 10.98 \\
197.30 & 11.46 \\
206.80 & 12.01 \\
211.21 & 12.23 \\
216.31 & 12.65 \\
235.14 & 13.47 \\
236.54 & 14.32 \\
254.00 & 16.61 \\
268.24 & 18.91 \\
273.24 & 19.34 \\
282.79 & 20.16 \\
295.10 & 21.99 \\
301.67 & 22.59 \\
\hline
\end{tabular}

Note: Determined using correlation lines shown in Figure $5 \mathrm{~A}$; assumes that the fine-scale features of Site 608 (age model 2) and Site 563 oxygen isotopic records correlate; used to construct Figure 5B.

Table 3E. Site 77 age model.

\begin{tabular}{lll}
\hline \multicolumn{1}{c}{ Criterion } & $\begin{array}{c}\text { Sub-bottom } \\
\text { depth } \\
(\mathrm{m})\end{array}$ & $\begin{array}{c}\text { Age } \\
\text { (Ma) }\end{array}$ \\
\hline FO Globigerina nepenthes & 178. & 11.3 \\
FO Praeorbulina spp. & 241. & 16.6 \\
FO Globorotalia kugleri & 317. & 23.6 \\
LO Chiloguembelina spp. & 375. & 30.0 \\
\hline Note: First occurrence = FO; last occurrence = \\
LO. Biostratigraphic data summarized by Mill- \\
er and Fairbanks (1985). Age models differ \\
slightly from Miller and Fairbanks (1985) be- \\
cause of reassignment of the G. nepenthes da- \\
tum from 12 Ma (W. A. Berggren, personal \\
communication, 1983) to 11.3 Ma (Miller, Au- \\
bry, et al., 1985; Berggren et al., in press b).
\end{tabular}

Table 3F. Site 289 age model.

\begin{tabular}{lcr}
\hline \multicolumn{1}{c}{ Criterion } & $\begin{array}{c}\text { Sub-bottom } \\
\text { depth } \\
(\mathrm{m})\end{array}$ & $\begin{array}{r}\text { Age } \\
(\mathrm{Ma})\end{array}$ \\
\hline FO Globorotalia margaritae & 156.5 & 5.6 \\
FO Globigerina nepenthes & 348.0 & 11.3 \\
FO Praeorbulina spp. & 510.0 & 16.0 \\
FO Globoquadrina dehiscens & 654.0 & 23.2 \\
\hline
\end{tabular}

Note: See Table 3E for explanation of FO and $\mathrm{LO}$. Biostratigraphic data summarized by Miller and Fairbanks (1985). Age models differ slightly from Miller and Fairbanks (1985) as a result of reassignment of the $G$. nepenthes datum from $12 \mathrm{Ma}$ (W. A. Berggren, personal communication, 1983) to $11.3 \mathrm{Ma}$ (Miller, Aubry, et al., 1985; Berggren et al., in press b).

\begin{tabular}{lcc}
\hline \multicolumn{1}{c}{ Criterion } & $\begin{array}{c}\text { Sub-bottom } \\
\text { depth } \\
(\mathrm{m})\end{array}$ & $\begin{array}{c}\text { Age } \\
(\mathrm{Ma})\end{array}$ \\
\hline Oligocene/Miocene boundary & 293.0 & 23.7 \\
LO Globorotalia opima opima & 315.5 & 28.2 \\
Top Zone NP23 & 330.5 & 30.3 \\
Top Zone NP22 & 349.9 & 34.6 \\
LO Ericsonia formosa & 356.0 & 35.1 \\
\hline
\end{tabular}

Note: See Table 3E for explanation of LO. Biostratigraphic data summarized by Miller (1982).

er et al., 1985).This high-silicate bottom water of southern origin has been attributed to Antarctic Bottom Water (AABW) (Lonsdale and Hollister, 1979), but is actually NADW mixed with a small amount of AABW that has passed through the Romanche Fracture Zone and returned north (Broecker and Peng, 1983; Broecker et al., 1985). At lesser depths $\left(2.4-4.0^{\circ} \mathrm{C} ;<3000 \mathrm{~m}\right)$, the eastern basin apparently is ventilated by a supply of NEADW and Labrador Sea Water.

In the Oligocene, flow from the south probably was impeded by the Azores-Gibraltar Rise (Fig. 1) and AzoresBiscay Rise, which had sill depths of 3000 to $3500 \mathrm{~m}$ (Miller and Tucholke, 1983). These barriers probably contributed to the isolation of the Iberian-Biscay basins, although today they are not effective barriers to bottomwater flow. The Charlie Gibbs Fracture Zone and numerous small fracture zones in the mid-ocean ridge provided conduits for east-west flow in the Oligocene to early Miocene (Miller and Tucholke, 1983). The subsidence of the other tectonic passage into the eastern North Atlantic, the Greenland-Scotland Ridge, is addressed in the Appendix.

All sites compared here (Table 1) were located at abyssal depths (greater than $2000 \mathrm{~m}$ ) during the Oligocene and Miocene. Site 608 can be "backtracked" (Sclater et al., 1971; Berger and Winterer, 1974; Sclater et al., 1977; Parsons and Sclater, 1977) using the equation:

$$
P d=I d+\mathrm{k} t^{1 / 2}-S
$$

where $P d=$ paleodepth, $I d=$ initial depth, $t=$ (age of basement - age of level considered), $S=$ sediment correction of $0.66 \times$ (basement depth sub-bottom - depth sub-bottom of level considered), and $k=a$ constant derived from empirical age versus subsidence curves. Knowing $\mathrm{k}$ and present depth $(\mathrm{Pr})$, initial depth for a site can be computed:

$$
I d=P r-\mathrm{k} t^{1 / 2}+S
$$

For the western North Atlantic, k has a value of 300 (computed from data of Tucholke and Vogt, 1979, solving equation 1 for $\mathrm{k}$, assuming $I d=2650 \mathrm{~m}$ ); for the Pacific, it has a value of 350 (Sclater et al., 1977). These equations are valid for crustal ages less than about $80 \mathrm{Ma}$ (Parsons and Sclater, 1977), which includes Sites 563, 608, and 77. For crustal ages greater than this (e.g., Site 289), subsidence follows the exponential curve:

$$
P d=I d-\mathrm{A}+\mathrm{A} \times \mathrm{e}^{(-t / \tau)}-s
$$




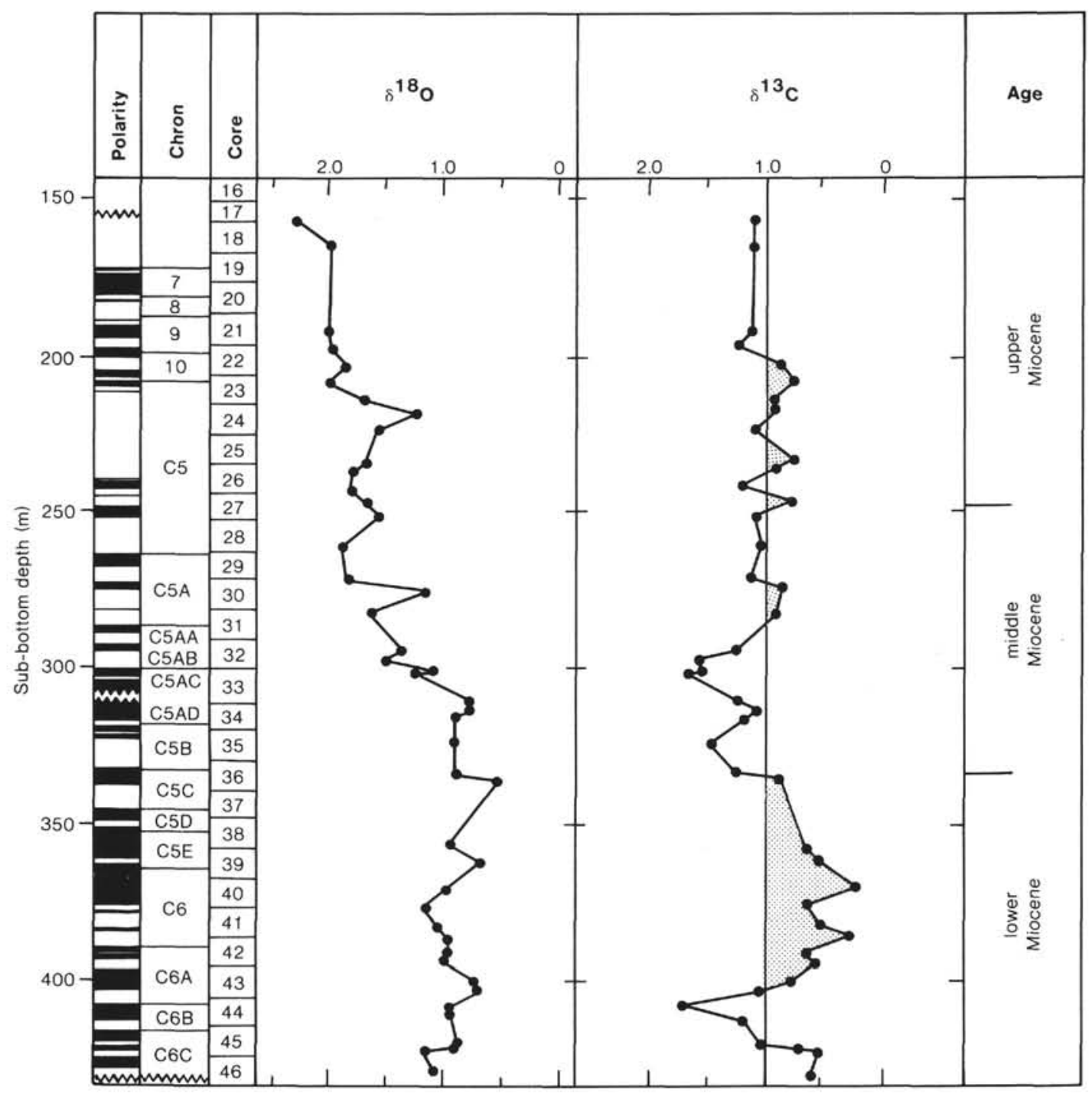

Figure 3. Oxygen and carbon isotopic values for the benthic foraminiferal taxon Cibicidoides spp. at Site 608 reported in parts per mille to PDB standard. The vertical line is drawn through the mean of $\delta^{13} \mathrm{C}$ values $(1.0 \%)$, and the depleted intervals are indicated with stipples. Magnetostratigraphic polarity patterns after Clement and Robinson (this volume); chron interpretations follow Clement and Robinson except for Chrons C6B to C6C. Chronostratigraphic subdivisions were drawn on the basis of magnetostratigraphy and the time scale of Berggren et al. (in press b).

where $\tau=62.5$ and $\mathrm{A}$ is an empirical constant of about -3650 for Pacific crust (computed using empirical data of Parsons and Sclater, 1977, table 2, solving equation 3 for A, assuming $I d=2700 \mathrm{~m}$ ).

Assuming simple thermal subsidence (equation 1), depths at Site 608 for the Miocene intervals investigated range from 3100 to $3500 \mathrm{~m}$; we assume that Site 608 was not uplifted significantly. This might not be the case, for Kings Trough is known to have been tectonically active in the Eocene-Oligocene (Kidd et al., 1982; Kidd and Ramsay, this volume). Nevertheless, Eocene-Oligocene uplift values for nearby Cantabria Seamount (Bay of Biscay) were estimated to be less than $1000 \mathrm{~m}$ (Miller, 1982). It is reasonable to assume, then, that Site 608 lay at depths greater than $2000 \mathrm{~m}$ in the Miocene, and benthic foraminifers are indicative of oceanic depths (Thomas, this volume). At Site 563, Miocene depths ranged from 3200 to $3600 \mathrm{~m}$, whereas Oligocene depths ranged from 2200 to $3200 \mathrm{~m}$. Miocene depths of $3600-4000$ and 2200-2300 m are computed for Sites 77 and 289, respectively. Based upon geological and thermal subsidence constraints, the Oligocene depth at Site 119 was estimated as approximately $4050 \mathrm{~m}$ (Miller, 1982).

\section{RESULTS AND DISCUSSION}

\section{Oxygen Isotopic Stratigraphy}

Oxygen isotopic values at Site 608 are relatively constant between 310 and $420 \mathrm{~m}$ sub-bottom (Fig. 3) (lower to lower middle Miocene). The $\delta^{18} \mathrm{O}$ values for this interval at Site 608 are slightly lower (approximately $0.3 \%$ ) than at Pacific sites at this time (Fig. 4), and are much lower (approximately $0.6 \%$ ) than at the western North Atlantic site (Fig. 5). This may be the result of differences in bottom-water temperature and/or seawater $\delta^{18} \mathrm{O}$ between basins. If ascribed entirely to temperature dif- 

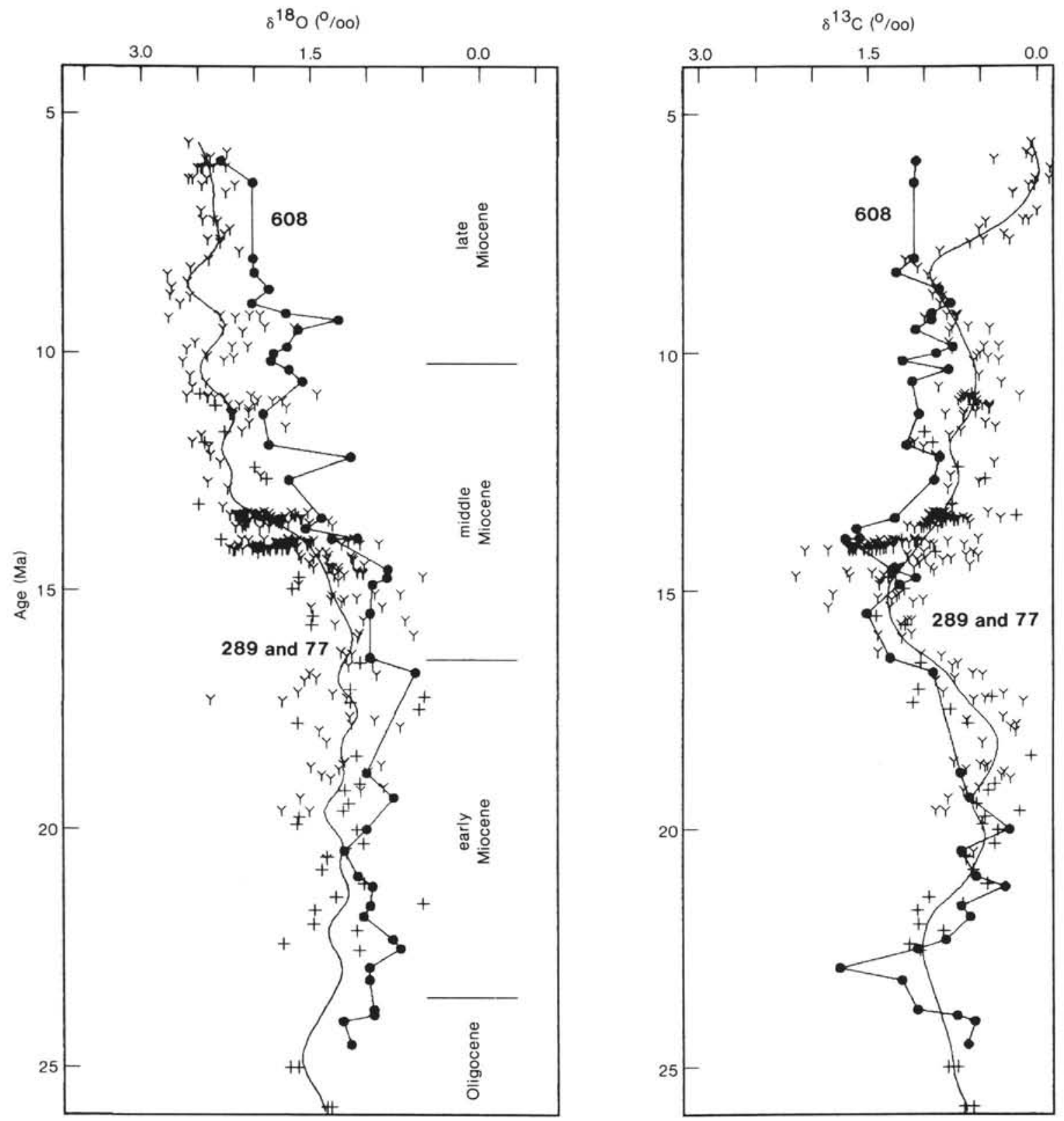

Figure 4. Age comparison of isotopic records from Pacific Sites 289 (Y) and 77 (+) with eastern North Atlantic 608 (closed circles). Sites 289 and 77 data after Savin et al. (1981). Curve drawn through data from Sites 289 and 77 was obtained by interpolating data from both sites to a constant time interval $(0.1 \mathrm{~m} . \mathrm{y}$.), and smoothing with a 21-point Gaussian convolution filter, eliminating frequencies less than $1 / \mathrm{m}$.y. This filter is essentially similar to a $1-\mathrm{m} . \mathbf{y}$. running mean. Age models for Sites 289 and 77 obtained by interpolating between biostratigraphic datum levels (Table 3E, F). Age model for Site 608 obtained from magnetostratigraphy (Fig. 3, Table 3A). Chronostratigraphic subdivisions drawn using the time scale of Berggren et al. (in press b).

ferences, these data indicate that the eastern North Atlantic was approximately $3^{\circ} \mathrm{C}$ warmer than the western basin and 1 to $2^{\circ} \mathrm{C}$ warmer than the Pacific.

Between 310 and $294 \mathrm{~m}$ sub-bottom (14.6-13.5 Ma), Site $608 \delta^{18} \mathrm{O}$ values increase to approximately $1.9 \%$ (Fig. 3). This increase correlates with the well-known early middle Miocene $\delta^{18} \mathrm{O}$ increase (Shackleton and Kennett, 1975; Savin, Douglas, et al., 1975; Savin, Douglas et al., 1981, Savin, Abel, et al., in press; Woodruff et al., 1981; among others). The increase at Site 608 appears to have been more gradual than that noted at Site 563 (Fig. 5A). The very sharp increase noted at Site 563 (Fig. 5A) may be due to a short (1-m.y.) hiatus, because Chrons C5B and C5AD are concatenated (Miller, Aubry, et al., 1985).

Authors of most oxygen isotopic studies have assumed that the earth was ice-free prior to the middle Miocene and that the middle Miocene $\delta^{18} \mathrm{O}$ increase represented the first Antarctic glaciation (e.g., Shackleton and Kennett, 1975; Savin, Douglas, et al., 1975; Savin, Douglas, et al., 1981; among others). Recent studies indicate periods of Oligocene glaciation (Miller and Fairbanks, 1983, 1985; Keigwin and Keller, 1984; Shackleton et al., 1984; Miller and Thomas, 1985; Poore and Matthews, 1984), 
A

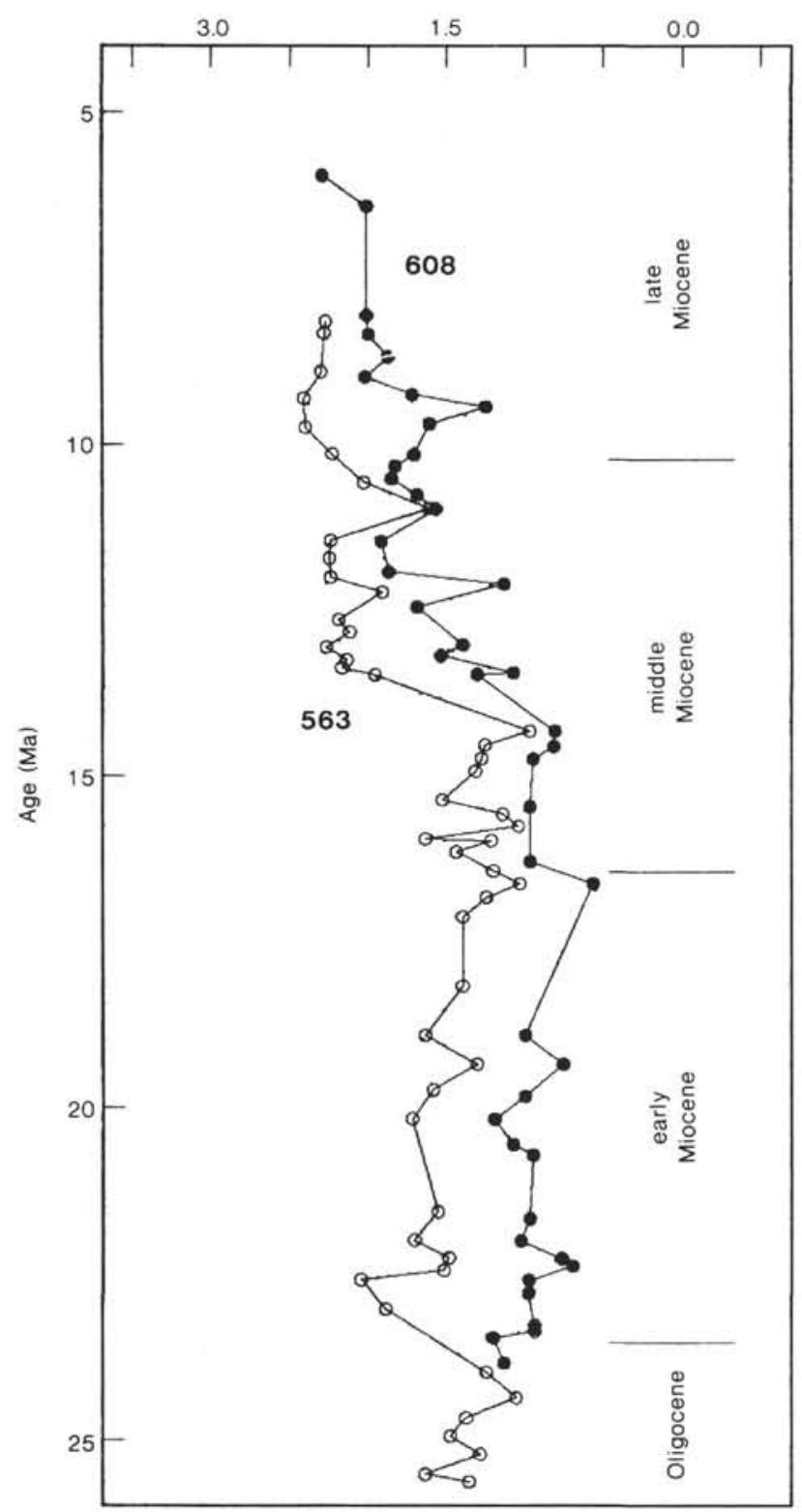

${ }^{13} \mathrm{C}(\% / 00)$

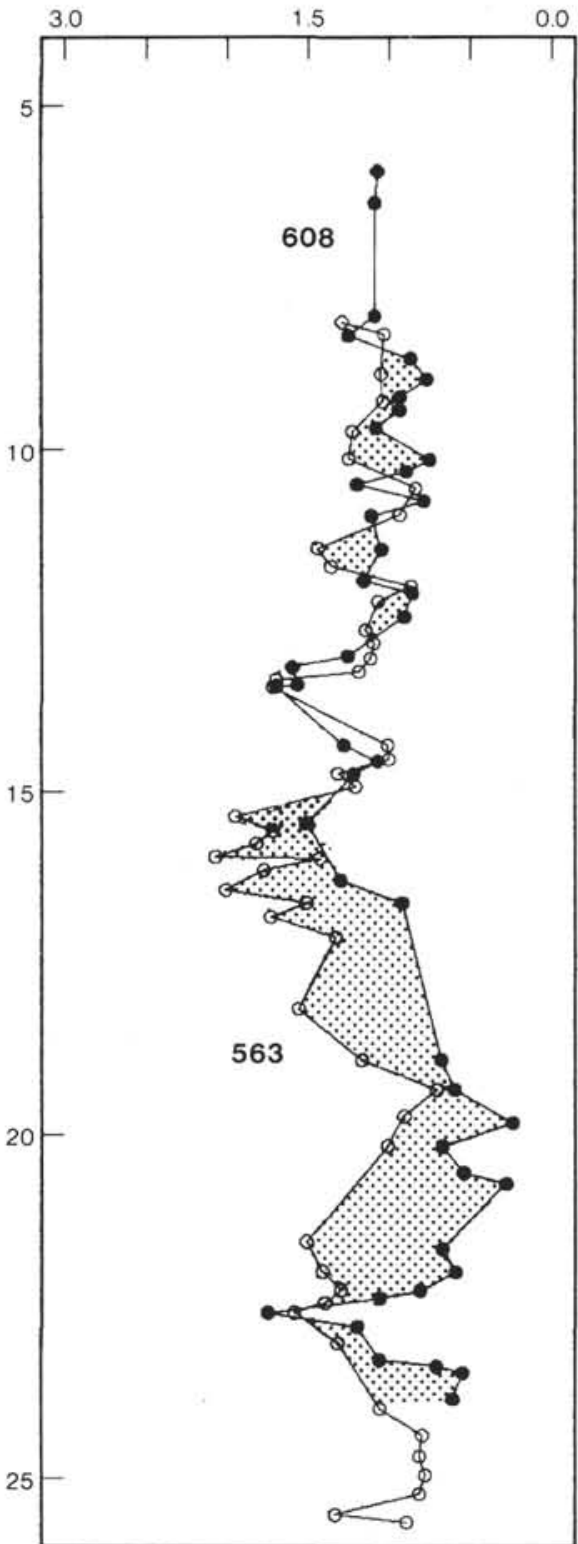

Figure 5. A. Age comparison of isotopic records from western North Atlantic Site 563 (open circles) (Miller and Fairbanks, 1985) and eastern North Atlantic Site 608 (closed circles). Correlation lines drawn between Site 563 and Site 608 oxygen isotopic records were used in deriving the age model for Fig. 5B. Age model for Site 563 derived by interpolating between magnetostratigraphic chron boundaries (Table 3C). Age model for Site 608 is that of Table 3A. Chronostratigraphic subdivisions drawn using the time scale of Berggren et al. (in press b). B. Age comparison assuming correlation between fine-scale $\delta^{18} \mathrm{O}$ structure between Sites 563 (open circles) (Miller and Fairbanks, 1985) and 608 (closed circles). Age models (Table 3B, D) differ from those in Figure 5A.

so the middle Miocene $\delta^{18} \mathrm{O}$ increase probably cannot be ascribed entirely to ice growth. Because the increase is greater than $1 \%$, it must represent either development of ice caps that exceeded present-day ice volume (which we regard as unlikely) or a combination of ice growth and bottom-water temperature decrease.

Detailed carbon isotopic comparisons between sites require better correlation control than that afforded by biostratigraphy. Magnetostratigraphy potentially provides such control; unfortunately, drilling disturbance and uncertainties in magnetostratigraphic identifications render correlations somewhat uncertain (Miller, Aubry, et al.,
1985; Clement and Robinson, this volume). Isotopic records provide a means for improving correlations between sites. We (1) assumed an age model for Site 608 based upon detailed magnetostratigraphy (Fig. 5B); (2) assumed that fine-scale Miocene $\delta^{18} \mathrm{O}$ changes at Site 563 correlate with Site 608 (viz., that the small variations noted on Fig. 5A correlate between sites); (3) used these changes as interpolation points for computing a different age model for Site 563 (Fig. 5B; Table 3D). The resulting comparison (Fig. 5B) shows improved correlation of the carbon isotopic records, although the major features are unchanged from the magnetostratigraphically derived age 

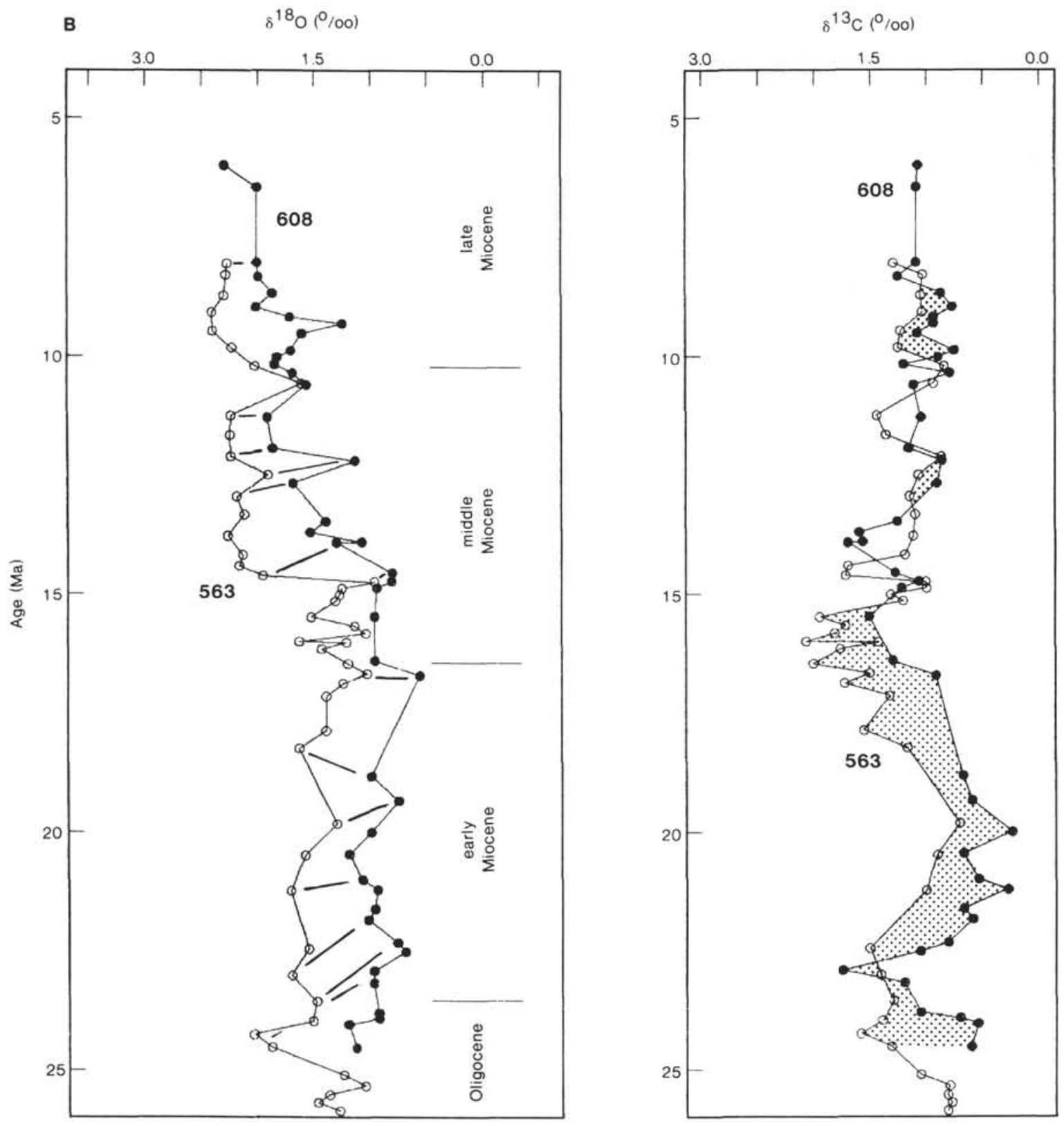

Figure 5 (continued).

model (Fig. 5B). Our data sets are not sufficient to "tune" the chronostratigraphic records with certainty; however, this exercise illustrates the potential for using oxygen isotopes for temporal control of carbon isotopic records. Another approach, using carbon isotopes to "tune" the oxygen isotopic record, also is a potential stratigraphic tool (e.g., Loutit et al., 1983).

\section{Carbon Isotopic Records and Abyssal Circulation}

The carbon isotopic record at Site 608 shows fluctuations with minima ranging from 340 to $400 \mathrm{~m}$ sub-bottom (17-22 Ma) and less prominent minima from 280 to $200 \mathrm{~m}$ (about 12.5-8.5 Ma). These fluctuations correlate with the global $\delta^{13} \mathrm{C}$ reported by Miller and Fairbanks $(1983,1985)$ (Figs. 4, 5). The global maximum noted at ca. 8-9 Ma in Pacific data (Fig. 4; fig. 1 in Woodruff and Savin, 1985) is poorly resolved at Site 608 because of limited sample resolution and "overprinting" by abyssal circulation effects.

Comparison of the carbon isotopic records from Site 608 with those from Pacific Sites 77 and 289 (Fig. 4) shows little difference prior to $15 \mathrm{Ma}$ (early Miocene). Between approximately 14 and $10.5 \mathrm{Ma}$ (middle Miocene) the eastern North Atlantic sites were generally higher in $\delta^{13} \mathrm{C}$ than the Pacific sites. From approximately 10.5 to $8 \mathrm{Ma}$, Pacific locations and Site 608 again were similar, but after this the eastern North Atlantic was again higher in $\delta^{13} \mathrm{C}$ than the Pacific. More data from Site 608 are needed to validate these differences, although we believe that the overall pattern will remain unchanged.

This comparison indicates supply of high $\delta^{13} \mathrm{C}$ bottom waters to the region of Site 608 (Kings Trough area) in the middle Miocene. If Kings Trough can be taken as representative of the eastern North Atlantic, this sug- 
gests supply of "younger" (higher oxygen, lower $\mathrm{CO}_{2}$, lower nutrients) bottom waters to this basin from 14 to $10.5 \mathrm{Ma}$ (middle Miocene) and 8 to $6 \mathrm{Ma}$ (late late Miocene), analogous to modern NADW. However, the lack of a Pacific-eastern Atlantic $\delta^{13} \mathrm{C}$ difference from 24 to $15 \mathrm{Ma}$ and 10.5 to $8 \mathrm{Ma}$ does not unequivocally indicate lack of bottom-water supply to the eastern basin. The similarity between Pacific records and Site 608 at these times may be due to absence or reduction of supply of young bottom waters to the eastern Atlantic basin. Alternatively, this similarity may be due to increased amounts of preformed nutrients in the source region for eastern North Atlantic bottom waters, as suggested for the glacial Pleistocene North Atlantic (Mix and Fairbanks, in press).

Comparisons of western and eastern North Atlantic records can be used to constrain the relative isolationventilation of the eastern basins. Basin-basin $\delta^{13} \mathrm{C}$ differences within the North Atlantic suggest that the abyssal circulation in Iberian and Biscay basins was relatively restricted prior to the middle Miocene. Comparison of the Site $608 \delta^{13} \mathrm{C}$ record with the western North Atlantic (Site 563) (Fig. 5A,B) record shows that the eastern location was lower in $\delta^{13} \mathrm{C}$ from 23 to $15 \mathrm{Ma}$ (early Miocene). After $15 \mathrm{Ma}$ there was little difference between eastern and western locations (Fig. 5). We suggest that Site 608 was more isolated than the western basin in the early Miocene. We interpret the rapid convergence of the Site 608 and Site $563 \delta^{13} \mathrm{C}$ records as reflecting increased ventilation of the Kings Trough area at ca. 15 Ma. This circulation change preceeded the middle Miocene $\delta^{18} \mathrm{O}$ increase (which occurred at about $14.6 \mathrm{Ma}$ ) by about $0.4 \mathrm{~m}$.y (Figs. 5A, B). We propose four possible hypotheses to explain the apparent increase in ventilation at Site 608 in the middle Miocene:

1. Eocene-Oligocene uplift in the Kings Trough vicinity resulted in tectonic isolation and local stagnation at Site 608 until the middle Miocene.

2. Climatically induced hydrographic changes (temperature decrease or salinity increase) at high latitudes in the North Atlantic and/or Norwegian-Greenland Sea resulted in increased bottom-water production. This hypothesis requires that surface hydrographic changes in these areas preceeded the middle Miocene global benthic $\delta^{18} \mathrm{O}$ increase by about 0.4 m.y.

3. Assuming that the source of high-oxygen bottom waters was advection from the western basin (including Labrador Sea and/or Denmark Strait Overflow), Site 608 may have been situated below the sill depth in the midocean ridge (Charlie Gibbs, Romanche fracture zones, or Azores-Gibraltar Rise) (Fig. 1). This situation would be analogous to the modern eastern equatorial basins, which are ventilated from the western equatorial Atlantic. In the Pleistocene, reduced flow of "NADW" resulted in decreased ventilation of the eastern equatorial Atlantic basins (Curry and Lohmann, 1983, 1985). By analogy, the middle Miocene increase in ventilation may be attributable either to an increase in the sill depths or to increased western basin ventilation and increased advection into the eastern basin.
4. Subsidence of the portion of the Greenland-Scotland Ridge between Iceland and the Faeroes in the middle Miocene resulted in increased supply of bottom water to the eastern basin.

We regard the local tectonic hypothesis (1) as unlikely. Oligocene carbon isotopic evidence from the Bay of Biscay (Site 119; Miller and Curry, 1982) indicates that the eastern basins were significantly less ventilated than the western basins, in agreement with the Site 608 record. Comparison of Site 119 with Site 563 (Fig. 6) clearly shows a dramatic difference, with very low $\delta^{13} \mathrm{C}$ values in the Bay of Biscay from approximately 33 to $30 \mathrm{Ma}$ ("middle" Oligocene). This period of inferred reduced advection correlates with an acme of Nuttallides umbonifera (Miller, 1982). Because this taxon is associated with low carbonate saturation (Bremer and Lohmann, 1982), its high abundance may be interpreted as indicating the presence of older, more corrosive water in the "middle" Oligocene of the Bay of Biscay (Miller, 1982) consistent with carbon isotopic comparisons.

The possibility that surface hydrographic changes in "NADW" source regions (hypothesis 2) caused the abyssal circulation change cannot be ruled out with the available data. Planktonic foraminiferal isotopic data from these potential source regions are needed to test this hypothesis (Mix and Fairbanks, in press). We regard this hypothesis as unlikely, because the $\delta^{13} \mathrm{C}$ convergence apparently preceded the $\delta^{18} \mathrm{O}$ increase (Fig. 5).

We also argue against the supply of bottom water solely from the western basin (hypothesis 3 ). Numerous small fracture zones in the mid-ocean ridge that were present in the Oligocene-early Miocene closed in the middle Miocene (Miller and Tucholke, 1983), suggesting that the middle Miocene circulation change was not due to increased advection across the mid-ocean ridge. However, because of possible tectonic complexities, backtracking estimates of the Romanche Fracture Zone (Bonatti and Chermack, 1982) and Azores-Gibraltar Rise (B. E. Tucholke, personal communication, 1985) may not be valid. Therefore, it is possible that increased advection into the Iberian-Biscay basins was due to subsidence of these sills. The hypothesis that bottom-waters were supplied to the Iberian-Biscay basins from the western basin via the Romanche Fracture Zone is testable with data from the Sierra Leone Rise (e.g., Curry and Lohmann, 1983).

We suggest that increased advection into the IberianBiscay basins was linked with a northern bottom-water source (hypothesis 4). The eastern basins of the northern North Atlantic probably had a bottom-water source from the Norwegian-Greenland Sea through the Faeroe Bank Channel (Fig. 7) during the Oligocene-early Miocene, albeit at a lower rate of supply than after $15 \mathrm{Ma}$. Seismic stratigraphic evidence indicates that widespread erosion occurred in the eastern and western basins of the northern North Atlantic in the Oligocene (Miller and Tucholke, 1983). Margin-intensified erosion caused by contour-following currents may be traced to the foot of the Wyville-Thompson Ridge/Faeroe-Shetland Channel system (Figs. 1, 2). Backtracking of the Faeroe Bank 

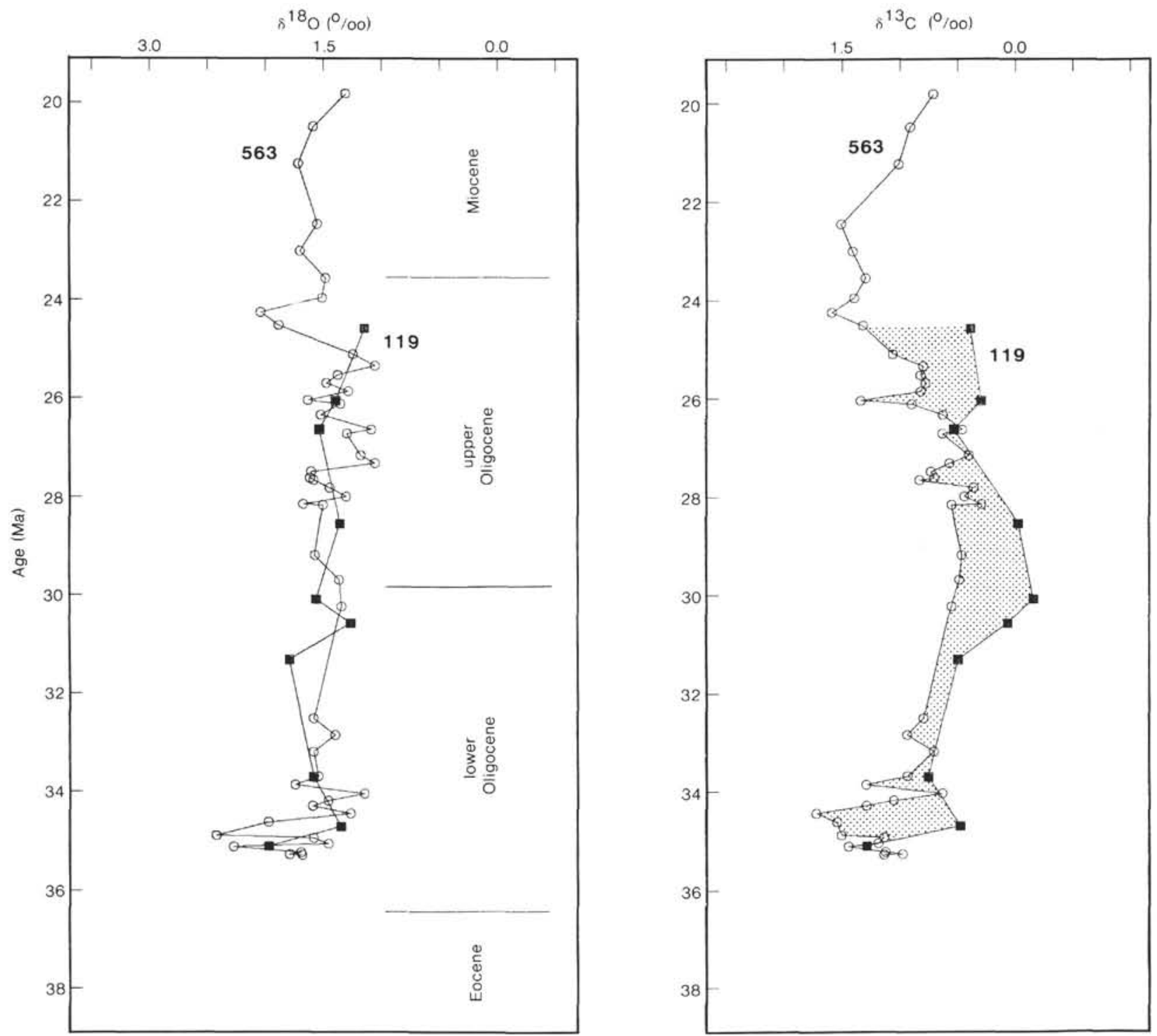

Figure 6. Age comparison of isotopic records from western North Atlantic Site 563 (open circles) (Miller and Fairbanks, 1985) and Bay of Biscay Site 119 (closed squares) (Miller and Curry, 1982). Chronostratigraphic subdivisions drawn using the time scale of Berggren et al. (in press a). Age model for Site 119 given in Table 3G.

Channel (modern sill depth about $900 \mathrm{~m}$; backtracked using equation 1 , basement age $=$ Anomaly $24,56 \mathrm{Ma}$, $\mathrm{k}=300$ ) suggests that it subsided below sea level by 36 Ma (earliest Oligocene) (Fig. 7). The Iceland-Faeroe Ridge (Figs. 2, 7) remained above sea level until about $21 \mathrm{Ma}$ (earliest Miocene) (on the basis of the same assumptions as above and a sill depth of about $475 \mathrm{~m}$; see also Thiede and Eldholm, 1983). By $15 \mathrm{Ma}$, the Iceland-Faeroe Ridge had subsided to about $150 \mathrm{~m}$ (Fig. 7) (see the Appendix for full discussion of backtracking of the GreenlandScotland Ridge).

The correlation of the subsidence of the Iceland-Faeroe Ridge with the abyssal circulation change in the middle Miocene suggests a causal relationship. We favor the following scenario: (1) subsidence of the Iceland-Faeroe Ridge below a given threshold resulted in a rapid increase of advection (Fig. 5) into the eastern basin at 15 $\mathrm{Ma}$; (2) the resulting increase in "NADW" may have triggered the global climate change at about 14.6 Ma (see also Schnitker, 1980a, b). This scenario is most satisfying in that it emphasizes the importance of "NADW" in modulating climate (Broecker et al., 1985).

Seismic and lithostratigraphic evidence indicates that other abyssal circulation changes predated increased advection into the eastern basins. The top of biosiliceous sediments in the northeastern North Atlantic correlates with Reflector R2 at about $17 \mathrm{Ma}$ (Miller and Tucholke, 1983). The association of Reflector R2 with several unconformities led Miller and Tucholke to conclude that this horizon represented an erosional pulse of bottom water (1983). These unconformities are best developed at western basin sites $(563,558,407)$ and eastern basin sites shallower than $3 \mathrm{~km}(406,555)$. Miller and Fairbanks (1985) noted a peak difference between Pacific and western North Atlantic $\delta^{13} \mathrm{C}$ records at about $17 \mathrm{Ma}$, which they interpreted as increased bottom-water supply 

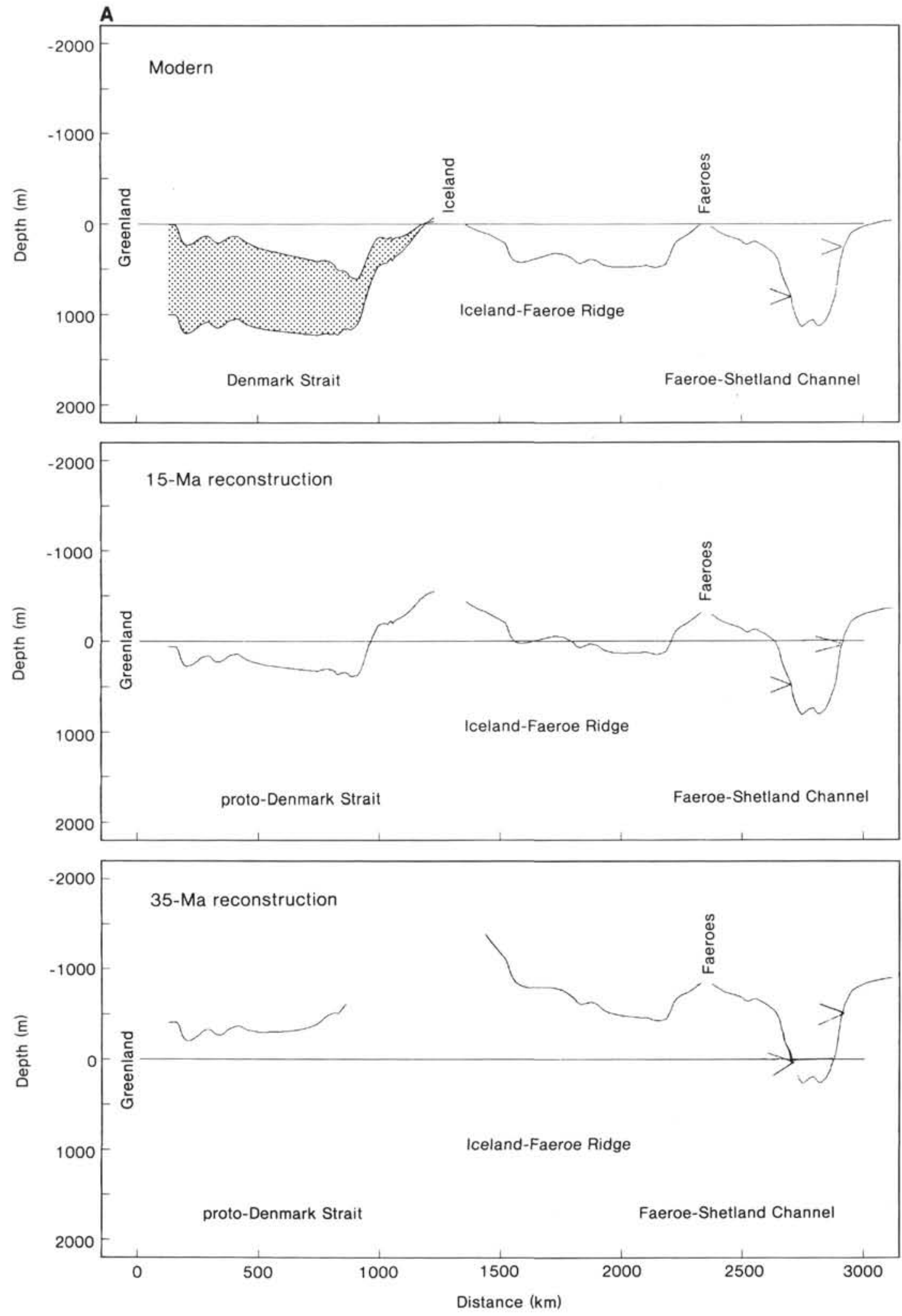

Figure 7. A. Tectonic reconstructions of the Greenland-Scotland Ridge across-sections A-B and C-D (Fig. 2) assuming simple thermal subsidence (equation 1), age models derived from Nunns (1983), and a sediment thickness in Denmark Strait of about $1 \mathrm{~km}$ (stippled area) (Larsen, 1983). See the Appendix for discussion. Portion between the Faeroe and Shetland islands does not cross sill depths; arrow points indicate sill depths for the Faeroe Bank Channel (deeper arrow) and Wyville-Thompson Ridge (shallower arrow). B. As in Figure 7A, but assuming $2 \mathrm{~km}$ of sediment in Denmark Strait (stippled area). 

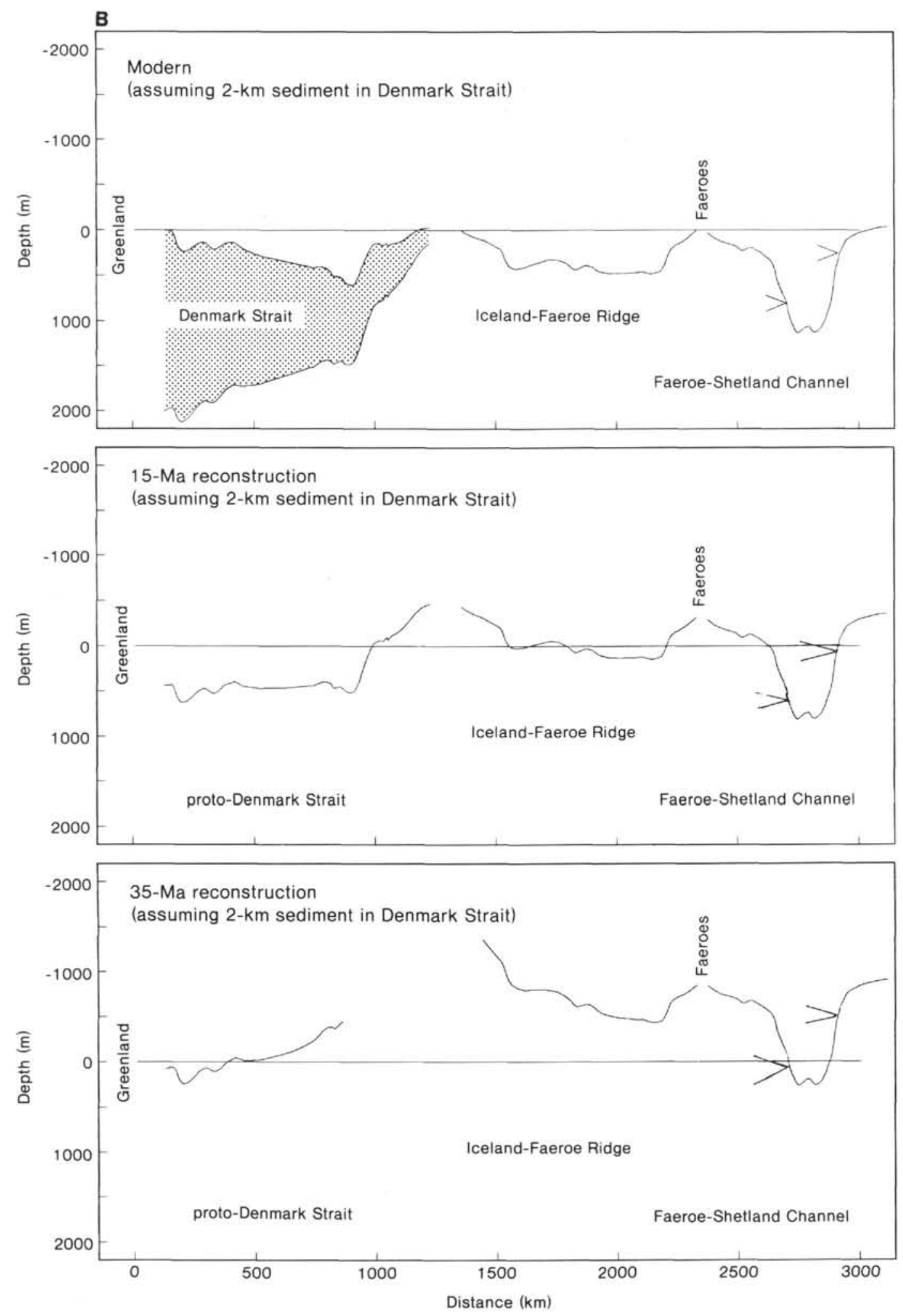

Figure 7 (continued).

associated with Reflector R2 (Miller and Fairbanks, 1985). However, Reflector R2 apparently correlates in time with little difference between Pacific and eastern basin $\delta^{13} \mathrm{C}$ values (Fig. 4) and continuous sedimentation at Site 608 (Clement and Robinson, this volume). We speculate that erosion associated with Reflector $\mathrm{R} 2$ was due to increased influx of bottom water to the western basin, but that advection into the deep eastern basin below 2 to $3 \mathrm{~km}$ remained relatively low. Erosion at sites shallower than 2 to $3 \mathrm{~km}$ in the eastern basin suggests the advection of 
western deep water into the eastern basin above this depth, perhaps analogous to the influx of modern Labrador Sea Water at similar water depths in the modern ocean (McCartney and Talley, 1982; Talley and McCartney, 1982).

The ventilation of the eastern basin may be sensitive to sea-level changes. From about 10.5 to $9 \mathrm{Ma}$, the $\mathrm{Pa}$ cific-eastern Atlantic $\delta^{13} \mathrm{C}$ difference was reduced (Fig. 4), suggesting reduced advection into the eastern basin. A sea-level lowering has been suggested for ca. $10 \mathrm{Ma}$ (Vail et al., 1977; Farre, 1985). Lowered sea level may have had an impact on the shallow Iceland-Faeroe sill (Fig. 7). Similar reduced advection into the eastern basin in the "middle" Oligocene (Fig. 6) was also linked with a sea-level lowering (Vail et al., 1977; Miller, Mountain, et al., 1985).

\section{CONCLUSIONS}

Abyssal circulation was quite different in the eastern and western northern North Atlantic basins in the Oligocene-early Miocene, in contrast to the situation in the modern ocean. The western basin had a ${ }^{13} \mathrm{C}$-enriched bottom-water source; however, the eastern basin was depleted in ${ }^{13} \mathrm{C}$ and presumably less ventilated. This difference between the Atlantic basins disappeared at about $15 \mathrm{Ma}$, correlating with subsidence of the part of the Greenland-Scotland Ridge between Iceland and the Faeroes (Fig. 7). Although bottom waters probably had entered the North Atlantic across portions of the Greenland-Scotland Ridge since the earliest Oligocene (Fig. 7), subsidence of the Iceland-Faeroe Ridge marked a breaking of a major tectonic threshold to the development of North Atlantic abyssal circulation. The general pattern of abyssal circulation in the North Atlantic has not changed since the middle Miocene, although it has been modulated by high-frequency climatic events (e.g. Fairbanks and Mix, in press).

\section{ACKNOWLEDGMENTS}

We thank W. B. Curry, D. Hodell, and M. E. Katz for reviewing the manuscript, B. Gruder for performing all isotopic analyses, M. E. Katz and S. Hambos for technical assistance, J. Thorne for discussions of "backtracking," B. E. Tucholke for discussions of the thermal history of the Greenland-Scotland Ridge, and A. D. Chave and A. C. Mix for software. Samples were provided by DSDP. This research was funded by NSF Grant OCE 8310086 and OCE 85 00859, a grant from the ARCO Foundation (KGM), and NSF Grant OCE 82 08784 (RGF). This is Lamont-Doherty Geological Observatory Contribution Number 3985.

\section{REFERENCES}

Baumgartner, A., and Reichel, E., 1975. The World Water Balance: Amsterdam (Elsevier).

Belanger, P. E., Curry, W. B., and Matthews, R. K., 1981. Core-top evaluation of benthic foraminiferal isotopic ratios for paleo-oceanographic interpretations. Palaeogeogr. Palaeoclimatol. Palaeoecol., 33:205-220.

Berger, W. H., 1970. Biogenous deep-sea sediments: fractionation by deep-sea circulation. Geol. Soc. Am. Bull., 81:1385-1402.

Berger, W. H., and Winterer, E. L., 1974. Plate stratigraphy and the fluctuating carbonate line. In Hsü, K. L., and Jenkyns, H. C. (Eds.), Pelagic Sediments on Land and Under the Sea. Int. Assoc. Sediment. Spec. Publ., 1:11-48.

Berggren, W. A., and Hollister, C. D., 1974. Paleogeography, paleobiogeography, and the history of circulation in the oceans. In Hay,
W. W. (Ed.), Studies in Paleo-oceanography. Soc. Econ. Paleontol. Mineral. Spec. Publ., 20:126-186.

Berggren, W. A., Kent, D. V., and Flynn, J., in press a. Paleogene geochronology and chronostratigraphy. In Snelling, N. J. (Ed.), Geochronology and the Geologic Time Scale. Geol. Soc. London Mem.

Berggren, W. A., Kent, D. V., and Van Couvering, J. A., in press b. Neogene geochronology and chronostratigraphy. In Snelling, N. J. (Ed.), Geochronology and the Geologic Time Scale. Geol. Soc. London Mem.

Bonatii, E., and Chermack, A., 1982. Formerly emerging crustal blocks in the equatorial Atlantic. Tectonophysics, 165-180.

Boyle, E. A., and Keigwin, L.D., 1982. Deep circulation of the North Atlantic over the last 200,000 years: geochemical evidence. Science, 218:784-787.

Bremer, M. L., and Lohmann, G. P., 1982. Evidence for primary control of the distribution of certain Atlantic Ocean benthonic foraminifera by degree of carbonate saturation. Deep Sea Res., 29: 987-998.

Broecker, W. S., and Peng, T.-H., 1983. Tracers in the Sea: Palisades: (Eldigeo Press).

Broecker, W. S., Peteet, D., and Rind, D., 1985. Does the ocean-atmosphere system have more than one stable mode of operation? Nature, 315:21-26.

Broecker, W., Rooth, C., Peng, T.-H., 1985. Ventilation of the deep northeastern Atlantic. J. Geophys. Res., 90(C4):6940-6944.

Curry, W. B., and Lohmann, G. P., 1982. Carbon isotopic changes in benthic foraminifera from the western South Atlantic: reconstruction of glacial abyssal circulation patterns. Quat. Res., 18:218235 .

1983. Reduced advection into Atlantic Ocean deep eastern basins during last glacial maximum. Nature (London), 306:577-580. 1985. Carbon deposition rates and deep water residence time in the equatorial Atlantic Ocean throughout the last 160,000 years. In Sundquist, E., and Broecker, W. (Eds.), The Carbon Cycle and Atmospheric $\mathrm{CO}_{2}$ : Natural Variations Archean to Present. Am. Geophys. Union Monogr., 32:285-302.

Duplessy, J.-C., Moyes, J., and Pujol, C., 1980. Deep water formation in the North Atlantic during the last ice age. Nature (London), 286:479-482.

Fairbanks, R. G., and Mix, A. C., in press. Carbon isotope variability of the southern ocean during the last 30,000 years. Nature.

Farre, J., 1985. The importance of mass wasting on the continental slope [Ph.D. dissert.]. Columbia University, New York.

Fuglister, F., 1960. Atlantic Ocean Atlas. Woods Hole Oceanographic Institution Atlas Ser. 1.

Graham, D. W., Corliss, B. H., Bender, M. L., and Keigwin, L. D., 1981. Carbon and oxygen isotopic disequilibria of Recent benthic foraminifera. Mar. Micropaleontol., 6:483-497.

Keigwin, L. D., 1980. Palaeoceanographic change in the Pacific at the Eocene-Oligocene boundary. Nature (London), 287:722-725.

Keigwin, L. D., and Keller, G., 1984. Middle Oligocene climatic change from equatorial Pacific DSDP Site 77. Geology, 12:16-19.

Kidd, R. B., Searle, R. C., Ramsey, A. T. S., Pritchard, H., and Mitchell, J., 1982. The geology and formation of Kings Trough, northeast Atlantic Ocean. Mar. Geol., 48:1-30.

Killingley, J. S., 1983. Effects of diagenetic recrystallization of ${ }^{18} \mathrm{O} /$ ${ }^{16} \mathrm{O}$ values of deep-sea sediments. Nature (London), 301:594-597.

Kroopnick, P., 1974. The distribution of ${ }^{13} \mathrm{C}$ in the Atlantic Ocean. Earth Planet. Sci. Lett., 49:469-484.

1980. Correlation between ${ }^{13} \mathrm{C}$ and $\mathrm{CO}_{2}$ in surface waters and atmospheric $\mathrm{CO}_{2}$. Earth Planet. Sci. Lett., 22:397-403.

1985. The distribution of $\mathrm{C}-13$ of $\mathrm{TCO}_{2}$ in the world oceans. Deep Sea Res., 32(1A):57-84.

Kroopnick, P., Weiss, R. F., and Craig, H., 1972. Total $\mathrm{CO}_{2},{ }^{13} \mathrm{C}$, and dissolved oxygen ${ }^{18} \mathrm{O}$ at GEOSECS II in the North Atlantic. Earth Planet. Sci. Lett., 16:103-110.

Larsen, B., 1983. Geology of the Greenland-Scotland Ridge in the Denmark Strait. In Bott, M. H. P., Saxov, S., Talwani, M., and Thiede, J. (Eds.), Structure and Development of the GreenlandScotland Ridge, NATO Conference Ser.: New York (Plenum Press), pp. $425-444$.

Lee, A., and Ellett, D., 1965. On the contribution of overflow water from the Norwegian Sea to the hydrographic structure of the North Atlantic Ocean. Deep Sea Res., 12:129-142. 
Lonsdale, P., and Hollister, C. D., 1979. A near-bottom traverse of Rockall Trough: hydrographic and geological inferences. Oceanol. Acta, 2:91-105.

Loutit, T., Pisias, N. G., Kennett, J. P., 1983. Pacific Miocene carbon isotope stratigraphy using benthic foraminifera. Earth Planet. Sci. Lett., 66:48-62.

McCartney M. S., and Talley, L. D., 1982. The subpolar mode water of the North Atlantic. J. Phys. Ocean., 12:1169-1188.

Miller, K. G., 1982. Late Paleogene paleoceanography of the Bay of Biscay: benthic foraminiferal evidence. Mar. Micropaleontol., 7: 403-440.

Miller, K. G., Aubry, M.-P., Khan, M. J., Melillo, A. J., Kent, D. V., and Berggren, W. A., 1985. Oligocene to Miocene biostratigraphy, magnetostratigraphy, and isotopic stratigraphy of the western North Atlantic. Geology, 13:257-261.

Miller, K. G., and Curry, W. B., 1982. Eocene to Oligocene benthic foraminiferal isotopic record in the Bay of Biscay. Nature (London), 296:347-350.

Miller, K. G., Curry, W. B., and Ostermann, D. R., 1985. Late Paleogene benthic foraminiferal paleoceanography of the Goban Spur Region, DSDP Leg 80. In Graciansky, P. C. de, Poag, C. W., et al., Init. Repts. DSDP, 80: Washington (U.S. Govt. Printing Office), 505-538.

Miller, K. G., and Fairbanks, R. G., 1983. Evidence for OligoceneMiddle Miocene abyssal circulation changes in the western North Atlantic. Nature (London), 306:250-253.

1985. Oligocene-Miocene global carbon and abyssal circulation changes. In Sundquist, E., and Broecker, W. (Eds.), The Carbon Cycle and Atmospheric $\mathrm{CO}_{2}:$ Natural Variations Archean to Present. Am. Geophys. Union Monogr., 32:469-486.

Miller, K. G., Mountain, G. S., and Tucholke, B. E., 1985. Oligocene glacio-eustasy and erosion on the margins of the North Atlantic. Geology, 13:10-13.

Miller, K. G., and Thomas, E., 1985. Late Eocene to Oligocene benthic foraminiferal isotopic record, Site 574, equatorial Pacific. In Mayer, L., Theyer, F., et al., Init. Repts. DSDP, 85: Washington (U.S. Govt. Printing Office), 771-777.

Miller, K. G., and Tucholke, B. E., 1983. Development of Cenozoic abyssal circulation south of the Greenland-Scotland Ridge. In Bott, M. H. P., Saxov, S., Talwani, M., and Thiede, J. (Eds.), Structure and Development of the Greenland-Scotland Ridge, NATO Conference Ser.: New York (Plenum Press), pp. 549-589.

Mix, A. C., and Fairbanks, R. G., in press. Late Pleistocene history of North Atlantic surface and deep ocean circulation. Earth and Planet. Sci. Lett.

Nunns, A. G., 1983. Plate tectonic evolution of the Greenland-Scotland Ridge and surrounding regions. In Bott, M. H. P., Saxov, S., Talwani, M., and Thiede, J. (Eds.), Structure and Development of the Greenland-Scotland Ridge, NATO Conference Ser.: New York (Plenum Press), pp. 11-30.

Parsons, B., and Sclater, J. G., 1977. An analysis of the variation of ocean floor bathymetry and heat flow with age. J. Geophys. Res., 82:803-827.

Poore, R. Z., and Matthews, R. K., 1984. Late Eocene-Oligocene oxygen and carbon isotope record from South Atlantic Ocean DSDP Site 522. In Hsü, K. J., LaBrecque, J. L., et al., Init. Repts. DSDP, 73: Washington (U.S. Govt. Printing Office), 725-736.

Savin, S. M., Abel, L., Barrera, E., Hodell, D., Keller, G., Kennett, J. P., Killingley, J., Murphy, M., Vincent, E., Woodruff, F., in press. The evolution of Miocene surface and near-surface marine temperatures: oxygen isotopic evidence. In Kennett, J. P. (Ed.), The Miocene Ocean: Paleoceanography and Biogeography. Geol. Soc. Am. Mem. 163.

Savin, S. M., Douglas, R. G., Keller, G., Killingley, J. S., Shaughnessy, L., Sommer, M. A., Vincent, E., and Woodruff, F., 1981. Miocene benthic foraminiferal isotope records: a synthesis. Mar. Micropaleontol., 6:423-450.

Savin, S. M., Douglas, R. G., and Stehli, F. G., 1975. Tertiary marine paleotemperatures. Geol. Soc. Am. Bull., 86:1499-1510.

Sclater, J. G., Abbott, D., and Thiede, J., 1977. Paleobathymetry of sediments of the Indian Ocean. In Heirtzler, J. R., et al. (Eds.), Indian Ocean Geology and Biostratigraphy: Washington (Am. Geophys. Union), pp. 25-59.
Sclater, J. G., Anderson, R. N., and Bell, N. L., 1971. Elevation of ridges and evolution of the central eastern Pacific. J. Geophys. Res., 76:7888-7915.

Schnitker, D., 1979. Cenozoic deep water foraminifers, Bay of Biscay. In Montadert, L., Roberts, D. G., et al., Init. Repts. DSDP, 48: Washington (U.S. Govt. Printing Office), 377-413.

1980a. Global paleoceanography and its deep-water linkage to Antarctic glaciation. Earth-Sci. Rev., 16:1-20.

1980b. North Atlantic oceanography as a possible cause of Antarctic glaciation and eutrophication. Nature, 284:615-616.

Shackleton, N. J., 1982. The deep-sea sediment record of climate variability. Prog. Oceanog., 11:199-218.

Shackleton, N. J., Hall, M. A., and Boersma, A., 1984. Oxygen and carbon isotope data from Leg 74 foraminifers. In Moore, T. C., Rabinowitz, P. D., et al., Init. Repts. DSDP, 74: Washington (U.S. Govt. Printing Office), 599-612.

Shackleton, N. J., Imbrie, J., and Hall, M. A., 1983. Oxygen and carbon isotope record of East Pacific core V19-30: implications for the formation of deep water in the late Pleistocene. Earth Planet. Sci. Lett., 65:233-244.

Shackleton, N. J., and Kennett, J. P., 1975. Paleotemperature history of the Cenozoic and the initiation of Antarctic glaciation: oxygen and carbon isotopic analyses in DSDP Sites 277, 279, and 281. In Kennett, J. P., Houtz, R. E., et al., Init. Repts. DSDP, 29: Washington (U.S. Govt. Printing Office), 743-755.

Shackleton, N. J., and Opdyke, N. D., 1973. Oxygen isotopic and palaeomagnetic stratigraphy of equatorial Pacific core V28-238: oxygen isotope temperatures and ice volume on a $10^{5}$ and $10^{6}$ year scale. Quat. Res., 3:39-55.

Talley, L. D., and McCartney, M. S., 1982. Distribution and circulation of Labrador Sea Water. J. Phys. Ocean., 12:1189-1205.

Thiede, J., and Eldholm, O., 1983. Speculations about the paleodepth of the Greenland-Scotland Ridge during the Late Mesozoic and Cenozoic times. In Bott, M. H. P., Saxov, S., Talwani, M., and Thiede, J. (Eds.), Structure and Development of the GreenlandScotland Ridge, NATO Conference Ser.: New York (Plenum Press), pp. $445-456$.

Tucholke, B. E., and Vogt, P. R., 1979. Western North Atlantic: sedimentary evolution and aspects of tectonic history. In Tucholke, B. E., Vogt, P. R., et al., Init. Repts. DSDP, 43: Washington (U.S. Govt. Printing Office), 791-825.

U.S. Naval Oceanographic Office, 1964. Chart of the World, No. 1262A (10th ed., rev.), Washington, D.C.

Vail, P. R., Mitchum, R. M., Jr., Todd, R. G., Widmier, J. M., Thompson, S., III, Sangree, J. B., Bubb, J. N., and Hatelid, W. G., 1977. Seismic Stratigraphy and global changes of sea level. In Payton, C. E. (Ed.), Seismic Stratigraphy-Applications to Hydrocarbon Exploration. Am. Assoc. petrol. Geol. Mem., 26:49-212.

Vincent, E., and Berger, W. H., 1985. Carbon dioxide and polar cooling in the Miocene: the Monterey hypothesis. In Sundquist, E., and Broecker, W. (Eds.), The Carbon Cycle and Atmospheric $\mathrm{CO}_{2}$ : Natural Variations Archean to Present. Am. Geophys. Union Monogr., 32:455-468.

Vincent, E., Killingley, J. S., and Berger, W. H., 1985. Miocene oxygen and carbon isotope stratigraphy of the tropical Indian ocean. In Kennett, J. P. (Ed.), Miocene Paleoceanography and Biogeography. Geol. Soc. Am. Mem., 163:103-130.

Woodruff, F., and Savin, S. M., 1985. $\delta^{13} \mathrm{C}$ values of Miocene Pacific benthic foraminifera: correlations with sea level and productivity. Geology, 13:119-122.

Woodruff, F., Savin, S. M., and Douglas, R. G., 1980. Biological fractionation of oxygen and carbon isotopes by Recent benthic foraminifera. Mar. Micropaleontol., 5:3-13.

1981. Miocene stable isotopic record: detailed deep Pacific ocean study and its paleoclimatic implications. Science, 212: 665-668.

Worthington, L. V., 1976. On the North Atlantic circulation. Johns Hopkins Oceanographic Studies, 6:110.

Date of Initial Receipt: 7 April 1985 Date of Acceptance: 25 October 1985 


\section{APPENDIX \\ Backtracking of Greenland-Scotland Ridge ${ }^{3}$}

The aseismic Greenland-Scotland Ridge is divided into three segments: the Denmark Straits between Greenland and Iceland, the Iceland-Faeroe Ridge, and the Faeroe-Shetland Channel/Faeroe Bank Channel/Wyville-Thompson Ridge system (Figs. 1, 2). We consider each segment individually.

\section{Iceland-Faeroe Ridge}

The backtracking of the Iceland-Faeroe Ridge is the best constrained of the segments. This portion of the ridge is oceanic crust; no sediment corrections need be made because the ridge crest is devoid of sediment (Miller and Tucholke, 1983). We assumed that Anomaly 13 (35.87 Ma) lay about $1429 \mathrm{~km}$ (Fig. 7) and interpolated to Anomaly 24 at about $2279 \mathrm{~km}$ (Fig. 7); these age constraints are tentative, because magnetic anomalies are poorly defined on the ridge crest (Nunns, 1983). Assuming simple thermal subsidence (equation 1), we obtained subsidence estimates for this portion of the ridge very similar to those of previous studies (e.g., Thiede and Eldholm, 1983; among others). We caution that the assumption of simple thermal subsidence may not be valid. If the tectonic change associated with the middle Miocene closing of Reykjanes Ridge fracture zones (Miller and Tucholke, 1983) was due to initiation or rejuvenation of the Iceland hot spot, then premiddle Miocene depths on the ridge may have been deeper.

\section{Faeroe-Shetland Channel/Faeroe Bank Channel/Wyville-Thompson Ridge System}

This ridge system, the deepest of modern sills, is apparently floored by continental crust of unknown age (see discussion in Miller and Tucholke, 1983). Acoustic basement in this region consists of flat-lying basalts of Anomaly 24 (56 Ma) age. Assuming complete thermal "resetting" of subsidence at $56 \mathrm{Ma}$ (Miller and Tucholke, 1983) as well as subsidence along an oceanic thermal subsidence curve, and neglecting sediments (again, allowed by the absence of sediments in the sills; Miller and Tucholke, 1983), provides a minimum estimate of subsidence (Fig. 7). If thermal subsidence was not completely reset, then the channel may have been deeper. Our estimate suggests that a connection through the Faeroe Bank Channel has existed since the end of

\footnotetext{
${ }^{3}$ See chapter proper for all equations, figures, and bibliographic references cited here.
}

the Eocene (Fig. 7) (see also Miller and Tucholke, 1983) but that a connection across the Wyville-Thompson Ridge did not develop until perhaps as late as 15 Ma (Fig. 7).

\section{Denmark Straits}

The spreading history of this portion of the ridge is the least known. A spreading ridge jump may have occurred on this portion of the aseismic ridge (see discussion in Miller and Tucholke, 1983). However, we assumed the following: Anomaly 24, near the Greenland side about $230 \mathrm{~km}$ (Fig. 7); Anomaly 21, about $410 \mathrm{~km}$; Anomaly 20, about 530 $\mathrm{km}$; Anomaly 18, about $660 \mathrm{~km}$; Anomaly 15, about $790 \mathrm{~km}$; and extrapolation of the age to $1226 \mathrm{~km}$.

These are reasonable interpretations of the magnetics of Nunns (1983); however, other interpretations are possible.

Larsen (1983) noted that the Denmark Strait is filled by 1 to $2 \mathrm{~km}$ of sediment. His limited sonobuoy coverage suggests that the best estimate near minimum width of the strait is about $1 \mathrm{~km}$ (his fig. 3). We used the following sedimentary basin (stippled area in Fig. 7A): thinning from $1 \mathrm{~km}$ to $0.8 \mathrm{~km}$ between $\mathrm{km} 129$ and 800 (Fig. 7A); thinning from $0.8 \mathrm{~km}$ to $0.4 \mathrm{~km}$ between $\mathrm{km} 800$ and 950 ; thinning from 0.4 to $0 \mathrm{~km}$ from $\mathrm{km} 950$ to 1200 (Fig. 7A, stippled area).

We assumed that two-thirds of the sediment was younger than 15 Ma (i.e., consistent with Larsen's [1983] estimate that most of the sediments were due to glacial input); we also assumed a linear sedimentation rate between basement age and $15 \mathrm{Ma}$ for the lower one-third of the sediment.

The results suggest that the Denmark Strait did not subside below sea level until after $35 \mathrm{Ma}$. However, assuming $2 \mathrm{~km}$ of sediment, the Denmark Straits subsided below sea level by $35 \mathrm{Ma}$ (Fig. 7B). We assumed: thinning from 2.0 to $1.0 \mathrm{~km}$ from $129 \mathrm{~km}$ to $800 \mathrm{~km}$; from 1.0 to $0.8 \mathrm{~km}$ from $800 \mathrm{~km}$ to $950 \mathrm{~km}$; and from $0.8 \mathrm{~km}$ to 0 from $950 \mathrm{~km}$ to $1200 \mathrm{~km}$ (Fig. 7B, stippled area).

If the Denmark Straits were closed in the early Oligocene as suggested by the model using $1 \mathrm{~km}$ of sediment (Fig. 7A), then the erosional event associated with Reflector R4 at the end of the Eocene must be attributed to formation of bottom water in the Labrador Sea/ Baffin Bay and/or northern North Atlantic (Miller and Tucholke, 1983). If a connection existed through the Denmark Straits in the Oligocene as suggested by the model using $2 \mathrm{~km}$ of sediments (Fig. 7B), then the erosional event associated with Reflector R4 may be attributed to influx of water from the Norwegian-Greenland Sea/Arctic Ocean, as postulated by Miller and Tucholke (1983). 